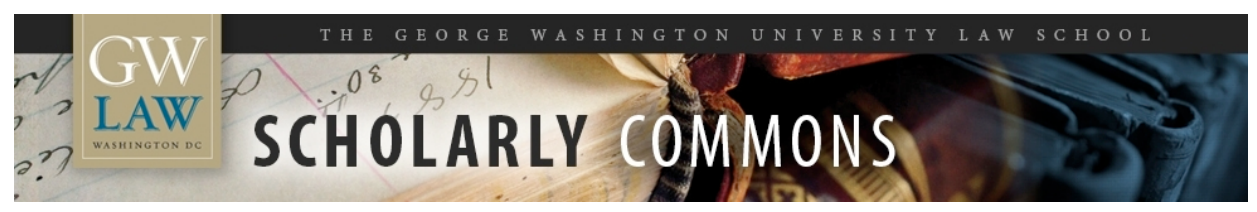

\title{
Compensating Commitments: The Law and Economics of Commitment Bonds That Compensate for the Possibility of Forfeiture
}

\author{
Michael B. Abramowicz \\ George Washington University Law School, abramowicz@law.gwu.edu \\ Ian Ayers
}

Follow this and additional works at: https://scholarship.law.gwu.edu/faculty_publications

Part of the Law Commons

\section{Recommended Citation}

Abramowicz, Michael B. and Ayers, lan, "Compensating Commitments: The Law and Economics of Commitment Bonds That Compensate for the Possibility of Forfeiture" (2010). GW Law Faculty Publications \& Other Works. 238.

https://scholarship.law.gwu.edu/faculty_publications/238

This Article is brought to you for free and open access by the Faculty Scholarship at Scholarly Commons. It has been accepted for inclusion in GW Law Faculty Publications \& Other Works by an authorized administrator of Scholarly Commons. For more information, please contact spagel@law.gwu.edu. 


\section{Contents}

I. SingLE ENTITY COMMITMENT BONDS............................................... 7

A. Compensating Commitments ................................................ 7

1. A Family of Incentive-Equivalent Approaches ......................... 7

2. A Behavioral Comparison .................................................. 11

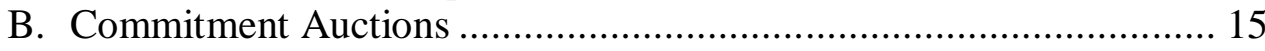

1. Informational Benefits .................................................. 15

2. Goal Setting Auctions .................................................... 17

II. COMMITMEnT BY THE GOVERnMENT ............................................... 19

A. The Legal Status of Governmental Commitment Bonds .................. 19

1. The Ambiguity of Existing Law .......................................... 20

2. A Normative Evaluation ...................................................... 23

3. Effects of Uncertainty about Constitutionality ......................... 26



1. The Credibility of Governmental Commitment......................... 28

2. Bondholder Political Influence ............................................. 30

C. Functions of Governmental Commitment ................................... 32

1. Vindication of Higher-Order Principles ................................. 32

a. Budget Balance .................................................................. 33

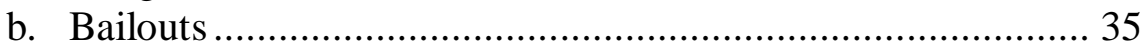

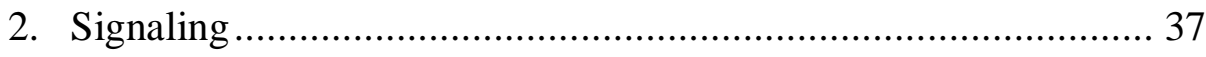

3. Facilitating Political Compromise ......................................... 39

a. Provisional Legislative Agreements ................................ 40

b. Sanding of Slippery Slopes ............................................ 41

III. MutUal COMMITMENT BondS ........................................................ 43

A. Reasons for Mutual Commitment ............................................... 44

1. Group Signaling ................................................................ 44

2. Unverifiable Conduct ........................................................... 46

3. Strategic Bargaining ........................................................... 48

B. Applications ......................................................................... 49

1. Commitments among Private Parties ...................................... 50

2. Commitments among Governments ....................................... 53

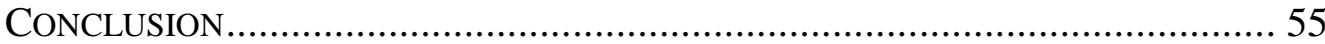


Determined that both his shipmates and he resist the call of the Sirens, Ulysses employs two devices. He instructs his men to put wax in their ears and to tie him to the mast so that he can experience the temptation yet resist it. ${ }^{1}$ Sometimes, though, it is not possible either to eliminate a temptation or to make it impossible to act on it. The modern literature on commitment highlights less constraining mechanisms that make a certain course of action less feasible or attractive without ruling it out altogether. A principal strategy is to enter into an arrangement in which one will suffer costs if one yields to temptation. ${ }^{2}$ For example, G. Terence Wilson describes weight-reduction programs in which "failure to meet predetermined goals may result in the client forfeiting a sum of money to his or her most disliked organization or political group."3

This Article describes what we call a "compensating commitment bond," which is a variation on this type of commitment mechanism. ${ }^{4}$ An individual or entity that wishes to commit itself using a conventional forfeiture promise faces the following trade-off: Placing funds at risk increases the chance that the party will achieve some goal; there is a chance of failure, however, and the expected costs of this failure must be balanced against the benefit of the increased

\footnotetext{
${ }^{1}$ HOMER, THE OdYSSEY bk. XII

2 Jon Elster, Ulysses Unbound: Studies in RATionality, Precommitment, And CONSTRAINTS 68-69 (2000).
}

3 G. Terence Wilson, Behavior Therapy and the Treatment of Obesity, in THE ADDICTIVE BEHAVIORS 207, 218 (W.R. Miller ed., 1980). This approach and some similar commitment strategies are implemented in a website of which one of us is a cofounder. See http://www.stickk.com/faq.php\#charities (last visited July 10, 2009) (noting that one can arrange to forfeit money either to a charity or to an "anti-charity"). That site, however, does not use or discuss the commitment bonds approach described here or provide any similar means for participants to receive an upfront benefit for agreeing to pay a cost if they should fail to reach their goals. Jon Elster describes this approach and one in which one receives a benefit for reaching a goal, but the benefit is received from money that a committing individual pays in advance, so the only difference from the costs scenario is whether the payment is made up front. ELSTER, supra note 2 , at 70 .

4 We use the word "commitment" in place of what the literature often refers to as "precommitment." Jon Elster notes the terminological confusion: "In Ulysses and the Sirens I referred to this phenomenon as 'precommitment' or 'self-binding.' Others have used the terms 'commitment' or 'self-commitment." ELSTER, supra note 2, at 4. We use the term "commitment" to be as inclusive as possible. The word "precommitment" seems redundant, because all commitments by definition are promises concerning the future.

At times, we will refer to "compensating commitment bonds" simply as "commitment bonds," in part because the concept of a bond already often denotes a financial instrument where the writer of the bond receives compensation. Distinguishing between compensating and noncompensating commitments is useful because some have used the "commitment bond" term to refer to non-compensating commitments. See, e.g., Tim Harford, You Bet! My Commitment Bond Adventure, http://blogs.ft.com/undercover/2007/11/you-bet-my-comm.html/ (Nov. 13, 2007). 
likelihood of success. The cost of some desired degree of commitment thus might not be worth the benefit. In contrast, a compensating commitment bond provides the party entering into the commitment some benefit (either definite or contingent) for entering into that commitment, thus offsetting the risk of forfeiture. That is, instead of simply promising to forfeit money to a charity in the event of a failed commitment, the committing party sells the right to receive any forfeited funds to a third party. The commitment is a fair bet rather than a oneway ratchet.

This Article develops the concept of compensating commitment bonds for their potential use in a range of legal applications. For initial illustrative purposes, however, consider someone who aims to lose thirty pounds in a year. Suppose that there is a $10 \%$ chance that the person can reach this goal without any form of commitment, but the probability will increase to $40 \%$ if the individual has $\$ 10,000$ at stake. With a conventional commitment, the person must decide whether a $30 \%$ increase in the probability of reaching the goal is worth putting $\$ 10,000$ at risk. With a commitment bond, however, the person can sell to a third party the right to receive the $\$ 10,000$ in the event of failure. Assuming symmetric information, a third party should be willing to pay almost $\$ 6,000$ for the $60 \%$ chance of receiving $\$ 10,000$.

If the third party did pay $\$ 6,000$, then the expected value to a risk neutral committing party would be zero, because the committing party would receive ex ante an amount equal to the expected cost of the forfeiture. In fact, the third party payment is likely to be less than $\$ 6,000$, given that the third party is accepting the risk of any expected enforcement costs. Additionally, assuming that the committing party is somewhat risk-averse, the committing party bears a risk cost. Nonetheless, entering into the commitment may be considerably more attractive than it would be without commitment bonds. The cost of the commitment produced by the commitment bond is the amount that it costs to induce the third party to bear the risk (causing the payment to fall short of $\$ 6,000$ ) plus the risk cost borne by the committing party. This is likely to be considerably less than the $\$ 10,000$ at risk.

Commitment bonds thus make commitment much more affordable, creating a range of applications that would otherwise be unattractive. Commitment bonds can help governments make credible policy. For instance, a government might use commitment bonds as a substitute for a constitutional balanced budget requirement by promising to compensate bondholders with $\$ 1$ for every dollar of budget deficit. ${ }^{5}$ Without the ex ante compensatory payment from the bondholders, it might be inadvisable for a government to take on this potential liability. The commitment benefit (assuming that there is a benefit from

\footnotetext{
${ }^{5}$ See infra Part II.C.1.a.
} 
such a commitment) might not be worth the expected payment. A commitment bond could be just as effective a deterrent as an uncompensated commitment, but at lower expected cost. If the government meets its commitment, it comes out ahead, and this benefit largely offsets the cost of failure, especially for a relatively risk-neutral entity like a government.

Our purpose is less to assess the strength of the normative case for any particular compensating commitment than to illustrate several classes of potential normative justifications for entering into compensating commitments. We will also consider applications of commitment bonds that illustrate their particular structural advantages and disadvantages. The balanced budget commitment is an example of a commitment bond that, like a constitutional provision but less strongly, seeks to ensure vindication of some high-order principle or preference. Commitments also might be used to send signals to third parties. For example, they can be used to assure holders of conventional bonds that inflation will be low or to facilitate political and legislative compromise.

Another possible legal use of a commitment bond is to enhance an individual's or entity's attractiveness as a contracting party. Indeed, the literature has already explored this subset of compensating commitment bonds. Robert Cooter and Ariel Porat explain that "when the promisor and promisee affect the probability of nonperformance or the magnitude of the resulting loss, efficient incentives require each of them to bear 100 percent of the resulting harm." ${ }^{6}$ The promisor, Cooter and Porat suggest, can promise to pay damages to a third party in the event some condition that is undesirable to the promisee occurs. This way, both parties have incentives to take care. Cooter and Porat call this "antiinsurance" because the promisor agrees to make a payment to the anti-insurer in the event of some bad contingency instead of receiving a payment from an insurer to compensate for such a contingency. ${ }^{7}$ In our terminology, an individual may

${ }^{6}$ Robert Cooter \& Ariel Porat, Anti-Insurance, 31 J. LEGAL STUD. 203, 204 (2002).

${ }^{7}$ One might extend the label "anti-insurance" to cover examples outside a contractual relationship. In some of our examples, including a simple weight loss contract, the label would make sense. The insured is receiving money instead of paying money, and then in the event of the bad contingency must pay money rather than receiving money. But there are other examples, even within the frame of contractual relationships considered by Cooter and Porat, in which the label makes less sense. For example, Cooter and Porat discuss the possibility of "anti-insurance for gains." Id. at 218-21. "When the promisor and promisee affect the probability or magnitude of a gain," they argue, "efficient incentives require each of them to bear 100 percent of the resulting gain." Id. at 218. A lawyer and client who is a plaintiff in a litigation might pay a third party in exchange for the third party's agreement to match the eventual recovery, so that the lawyer and client each receive $100 \%$ of the damages and thus each has optimal effort incentives. Here, the arrangement also differs from a standard insurance contract but in a different way; the insured makes an up-front payment for a right to receive money in the event of a good contingency. We prefer the label "commitment bonds" because it has applicability beyond contexts that seem related to insurance, and because the word "bond" emphasizes the purpose of the arrangement: that an individual or entity is seeking 
usefully enter into a commitment bond as a contractual concession to another party. What Cooter and Porat do not consider is that commitment bonds may be useful outside of being a substitute for contractual provisions like warranties that would have undesirable incentive effects. ${ }^{8}$ Cooter and Porat's focus on contracts leads them to overlook the possibility that a single party wanting to commit could beneficially sell a compensating commitment bond. ${ }^{9}$ They thus also do not recognize the possibility that government could use commitment bonds to achieve self-restraint.

This Article introduces and develops the concept and potential uses of commitment bonds. Part I.A describes single entity commitment bonds and explains the role of commitment bonds in signaling resolve while showing how the sale of such bonds may compensate the committing party for potential forfeitures arising out of the commitment. Part I.B then describes a family of incentive-equivalent bonds that vary the timing and contingency of cash flows and explains how auctioning commitment bonds creates the opportunity for the bonding process to aid in the process of goal setting itself.

Part II considers single entity commitment bonds in the governmental context. Part II.A discusses whether the government can enter into commitment bonds as a legal matter, and Part II.B considers other challenges to commitment by the government, such as whether those commitments would be credible. Part II.C continues by discussing the functions of governmental commitment and examining specific examples where government commitment bonds may be useful.

Part III considers mutual commitment bonds, in which two or more parties individually agree to enter into a commitment bond with an external party. Mutual commitment bonds differ from single party bonds because each party is motivated to commit because it wants another party to constrain itself. Part III.A develops reasons for mutual commitment bonds, and Part III.B explores potential legal

to bind itself. Cooter and Porat's focus on contractual contexts disguises the fact that the central aspect of an anti-insurance contract is that an individual or entity seeks or agrees to constrain itself. Our label reinforces that bonds are a mechanism by which a party can do so.

${ }^{8}$ The first sentence of Cooter and Porat's paper reveals the contractual frame and motivation of their analysis: "Promises pose a dilemma for incentives." Id. at 203. When Cooter and Porat compare anti-insurance to other legal devices, the comparison is to other tools of contract law. Id. at 223-25. Some of their conclusions are specific to the contractual context and might be different for other commitment bonds. For example, they argue, "Anti-insurance contracts are especially appropriate for one-shot transactions rather than for repeated interactions." Id. at 215.

${ }^{9}$ Even Cooter and Porat's formal model involves two contracting parties. They note, "At time 0 , the anti-insurer gives $\left(p_{a}, p_{b}\right)$ to $\mathrm{A}$ and $\mathrm{B}$, respectively, where $p_{a}$ and $p_{b}$ are positive for antiinsurance for losses and negative for anti-insurance for gains." Id. at 230. They thus ignore the possibility in which $p_{a}$ or $p_{b}$ equals zero. 
applications for mutual commitment bonds among private parties and among governments.

\section{SINGLE ENTITY COMMITMENT BONDS}

Far and away the most important aspect of compensating commitment bonds is the idea that the prospect of compensation for expected forfeitures radically reduces the cost of committing without reducing the incentive to follow through on the commitment. People have been using commitment devices for centuries to increase their own resolve or to credibly signal that resolve to others. The ability to achieve this while simultaneously being compensated for the expected forfeitures should by itself expand the demand for such devices. In this Part, we will describe a family of incentive-equivalent commitment bond implementations that vary the timing and contingency of the cash flows. We will focus on three implementations (which we call the ex ante, ex post, and wager implementations) that have particular salience. We will also describe the behavioral and structural factors that tend to make particular implementations more effective.

We will also show that auctioning commitment bonds creates the opportunity for the bonding process to aid in the process of goal setting itself. Commitment bond auctions are a kind of market mechanism that generates thirdparty assessments of the likelihood of commitment success. But instead of choosing the goal and the stakes and letting the subsequent auction reveal the probability of success, it is possible for the committing party to choose the goal and the desired probability of success. Then the committing party would let the market determine the minimum stakes that are required. Or, for goals that are susceptible to continuous variation (such as weight-loss or budget deficits or energy conservation), it is possible to choose the stakes and the desired probability of success and let the market choose the maximally obtainable goal. Commitment bond auctions can allow the market to signal to the committing party how best to set the stakes or even the commitment goal.

\section{A. Compensating Commitments}

\section{A Family of Incentive-Equivalent Approaches}

In our earlier example, we imagined a weight-loss commitment bond where the committing party put $\$ 10,000$ at risk if the party did not weigh thirty pounds less at the end of one year. Assuming that \$10,000 stakes created a 40\% chance of success and abstracting away from real-world transaction and enforcement costs as well as the time-value of money, potential counterparties should be willing to pay close to $\$ 6,000$ to purchase the potential $\$ 10,000$ 
forfeiture. The upfront payment of $\$ 6,000$ is the expected forfeiture $(60 \% \mathrm{x}$ $\$ 10,000)$, and the exchange of the unconditional ex ante payment for the conditional ex post forfeiture makes the commitment bond a fair bet to both sides. We call this version of a commitment bond the ex ante implementation.

But commitment bonds can be structured in other ways. For example, the committing party could put $\$ 10,000$ at risk (promising to pay a counterparty this amount upon failing to keep the commitment), and counterparties would make offers of an amount that must be paid to the committing party ex post if the committing party succeeds in keeping the commitment. We call this version of a commitment bond the ex post implementation, because the committing party receives only the possibility of ex post compensation without any ex ante compensation. Because the counterparty must pay only if the committing party succeeds, the offers will generally be higher. For example, if the probability of success remained at $40 \%$, counterparties should be willing to offer a contingent payment of $\$ 15,000$ for success in exchange for the right to receive $\$ 10,000$ for commitment failure (40\% x $\$ 15,000=60 \%$ x $\$ 10,000)$.

Below, we will focus on the behavioral impact of alternative commitment frames, but in the neoclassical model, the foregoing example produces a $\$ 25,000$ incentive for the committing party to keep her commitment. The committing party earns $\$ 15,000$ if she succeeds and loses $\$ 10,000$ if she fails, for a combined difference of $\$ 25,000$. This larger incentive might well increase the probability of success and hence reduce the amount that counterparties would be willing to offer to below $\$ 15,000$. It is possible, however, to derive an incentive-equivalent ex post implementation. If the committing party reduced her potential forfeiture to just $\$ 4,000$, counterparties would be willing to offer $\$ 6,000$ in ex post compensation. A counterparty should expect this amount of contingent compensation to produce a $40 \%$ of success, because the committing party, as with the ex ante implementation example, would have a total incentive of $\$ 10,000$ (the $\$ 6,000$ carrot plus the $\$ 4,000$ stick). This ex post implementation would be a fair bet because a contingent payment of $\$ 6,000$ would have the same expected value $(40 \% \times \$ 6,000)$ as the contingent forfeiture of $\$ 4,000(60 \%$ x $\$ 4,000)$.

A surprising result (which we prove in a footnote ${ }^{10}$ ) is that for incentiveequivalent implementations, the incentive-equivalent ex ante and ex post

\footnotetext{
10 Let:

$E P F=$ ex post forfeiture if commitment failure

$E P C=$ ex post compensation, if commitment success

$I=E P C-E P F$, equals total commitment incentive

$P=$ probability of success given level of incentive stakes

$E A C=$ ex ante compensation that bidder would be willing to bid if $\mathrm{EPC}=0$ and for
} chance to receive EPF.

$B=$ bid for right to $S$ in event of failure $(1-P)$, where entire bid is paid ex ante 
compensations will be equal. In the above examples, counterparties will either pay $\$ 6,000$ ex ante for a potential forfeiture of $\$ 10,000$, or offer $\$ 6,000$ ex post for a potential forfeiture of $\$ 4,000$. For constant forfeiture amounts, the ex post compensation will always be greater than the ex ante compensation, because the ex post compensation needs to be paid only if the commitment is a success. But to maintain a constant commitment incentive, the forfeiture amount can be substantially lower with ex post compensation. It turns out the lower forfeiture amount exactly offsets the high ex post compensation effect. So, abstracting away from behavioral biases such as loss aversion, one would expect in the neoclassical model that the present value of compensation would be the same for both the ex ante and ex post implementation.

A problem with both these ex ante and ex post implementations is that third party bond holders may have difficulty collecting the forfeitures if the committing parties fail to keep their commitment. So far, we have varied the timing of the payment to the committing party, but we can also vary the timing of the payment from the committing party. A simple approach forces the committing party to pay an upfront deposit of any required forfeiture amount - the deposit being returned in full if the commitment is kept. Thus, instead of receiving $\$ 6,000$ in ex ante compensation in exchange for putting at risk $\$ 10,000$ to be paid in the future, one could imagine being required to put $\$ 10,000$ down as an ex ante deposit to make sure that the $\$ 10,000$ forfeiture can actually be paid. On net, the committing party would pay $\$ 4,000$ ex ante (placing a $\$ 10,000$ deposit but receiving ex ante compensation of $\$ 6,000)$ and would receive the $\$ 10,000$ deposit back if she succeeds (and nothing back if she fails). We call this version the wager implementation, because the timing of the cash flows closely resembles those of traditional bookie wagers. This approach is also incentive-equivalent: the

$B C=$ bid for right to $S$ in event of failure $(1-P)$, where bid is contingent and only paid in event of success, and

$I=$ total incentive.

Using these it possible to derive that in a competitive equilibrium, the ex ante (unconditional) bid: $B=S *(1-P)$. And since in the ex ante implementation $\mathrm{I}=\mathrm{S}$, we can restate the ex ante bid amount as

$B=I^{*}(1-P)$.

In contrast, the ex post (conditional) bid amount in equilibrium should be such that the bidder's probable cost of compensation equals the probable benefit of forfeiture: $B C * P=S *(1-P)$. For the ex post implementation we also know that the total commitment incentive will equal: $I=B C+$ $S$, so $S=I-B C$. By substitution and manipulation, we have

$B C * P=(I-B C) *(1-P)$

$B C * P=I-B C-I P+B C^{*} P$

$B C=I-I P=I *(1-P)$,

which is equal to (1). 
only difference from the ex ante approach is the deposit ensuring that the committing party will be able to meet its obligations.

Table 1 summarizes the cash flows from these three implementations. All three are incentive-equivalent, because in each case the difference between the ex post compensation (which is contingent on success) and the ex post forfeiture (which is contingent on failure) is a constant $\$ 10,000$. Moreover, each of these three implementations holds one of the three cash flows to zero: (1) the ex ante implementation has no ex post compensation and from an ex post perspective is purely a stick incentive; (2) the wager (or ex ante deposit) implementation has no ex post forfeiture and from an ex post perspective is purely a carrot incentive; and (3) the ex post implementation has no ex ante compensation and from an ex post perspective is a mixture of carrots and sticks.

Table 1: An Example of the Family of Incentive-Equivalent Implementations

\begin{tabular}{|l|l|l|l|} 
Implementation & \multicolumn{1}{|l|}{$\begin{array}{l}\text { Ex ante } \\
\text { compensation }\end{array}$} & \multicolumn{1}{l}{$\begin{array}{l}\text { Ex post } \\
\text { compensation }\end{array}$} & \multicolumn{1}{l|}{$\begin{array}{l}\text { Ex post } \\
\text { forfeiture }\end{array}$} \\
\hline Ex Ante & 6,000 & 0 & $-10,000$ \\
\hline Ex Post & 0 & 6,000 & $-4,000$ \\
\hline Wager & $-4,000$ & 10,000 & 0 \\
\hline General & $6,000-K$ & $K$ & $K-10,000$ \\
\hline
\end{tabular}

The final row of Table 1 shows that these three implementations are special cases in a larger class of incentive-equivalent commitment bond implementations, all of which merely subtract some constant $(K)$ from the ex ante compensation and add the same amount to both of the ex post cash flows. This generalization allows us not only to see the underlying links between the three core implementations, but also to generate additional incentive equivalent implementations where all three cash flows are non-zero. For example, setting $K$ equal to $\$ 3,000$ constructs a scenario where counterparties pay $\$ 3,000$ in ex ante compensation to receive the chance to win $\$ 7,000$ in ex post forfeiture but take on the obligation to pay an additional $\$ 3,000$ in ex post compensation if the committing party succeeds. As we'll soon argue, this larger family of incentiveequivalent implementations is more than a theoretical curiosity. In a world with liquidity constraints and cognitive biases, it gives policy makers a richer toolbox of instruments from which to choose.

The above examples hold the incentive constant at $\$ 10,000$ and assumes that this incentive, regardless of whether it is implemented through carrots or sticks, produces a constant probability of success of $40 \%$. More generally within the neoclassical model, we could define the total commitment incentive, I, to be:

$$
I=E P C-E P F
$$


where $E P C$ is the ex post compensation (which is contingent on success) and $E P F$ is the ex post forfeiture (which is contingent on failure). Then if we let $P(I)$ be the probability of commitment success given a commitment incentive, then the expected forfeiture from the ex ante implementation, $E F$, for any particular $I$ will be:

$$
E F=(1-P(I))^{*} I \text {. }
$$

With these definitions, Table 2 reports a more general statement of the family of incentive-equivalent commitments. For example, if a $\$ 20,000$ incentive produced a $75 \%$ probability of success, then $I=\$ 20,000$ and $E F=\$ 5,000$. So we could expect a counterparty to pay close to $\$ 5,000$ in ex ante compensation for the chance to receive a $\$ 20,000$ forfeiture. Alternatively, counterparties would offer up to $\$ 5,000$ in ex post compensation for the chance to receive a $\$ 15,000$ forfeiture. Or, the committing party would put down $\$ 15,000$ ex ante and receive $\$ 20,000$ from counterparties in the event of success. All of the implementations, including the more general $K$-constant implementations, are fair bets, because the expected compensation from the counterparty equals the expected forfeiture to the counterparty. ${ }^{11}$

Table 2: A General Description of Outcomes for a Family of IncentiveEquivalent Implementations

\begin{tabular}{|l|l|l|l|}
\hline Implementations & $\begin{array}{l}\text { Ex ante } \\
\text { compensation }\end{array}$ & \multicolumn{1}{|l|}{$\begin{array}{l}\text { Ex post } \\
\text { compensation }\end{array}$} & $\begin{array}{l}\text { Ex post } \\
\text { forfeiture }\end{array}$ \\
\hline Ex Ante & $E F$ & 0 & $-I$ \\
\hline Ex Post & 0 & $E F$ & $E F-I$ \\
\hline Wager & $E F-I$ & $I$ & 0 \\
\hline General & $E F-K$ & $K$ & $K-I$ \\
\hline
\end{tabular}

\section{A Behavioral Comparison}

While the family of implementations described in Table 2 is somewhat redundant in a stylized world without transaction or enforcement costs or cognitive biases, different implementations can produce different results when we move away from these assumptions. For example, as mentioned above, difficulty in enforcing ex post forfeitures will drive the parties toward the wager implementation. Conversely, the ex ante implementation will be favored in

\footnotetext{
${ }^{11}$ From the general, $K$-constant, implementation we can see that the expected a bidder's expected payments and receipts would be: $E F-K+P K+(1-P)(K-I)=0$.

Substituting $E F=(1-P) I$, we have

$(1-P) I-K+P K+K-P K-(1-P) I=0$,

where the left-side simplifies to 0 , indicating that the cash flows are a fair bet.
} 
circumstances where the committing party is concerned that the counterparty will not pay the ex post compensation if there is commitment success. The ex post implementation (as one in a range of constant $K$ implementations) splits the difference - placing some risk of enforcement on both the counterparty and the committing party.

Alternatively, if the question is not one of enforcement but of liquidity, then we can again see nonequivalence among the implementations. In the foregoing example, where a $\$ 10,000$ incentive produced a $40 \%$ chance of success, if the committing party has only $\$ 5,000$, then the ex ante implementation (with its potential $\$ 10,000$ forfeiture) would be infeasible, whereas the ex post implementation (with its $\$ 4,000$ forfeiture) or the wage implementation (with its $\$ 4,000$ ex ante deposit) would be feasible. ${ }^{12}$ Or, if the counterparties are liquidity constrained, then the wager implementation (which in the foregoing example requires a potential $\$ 10,000$ ex post compensation) is less feasible than the ex ante or ex post implementations (which require only $\$ 6,000$ payments) to support the same incentive amount.

The picture becomes even more interesting if committing parties exhibit cognitive deviations from traditional expected utility theory. For example, if the committing party exhibits loss aversion, ${ }^{13}$ then committing parties will work harder to avoid failure when incentives are framed as contingent punishments (sticks) than as contingent rewards (carrots). Returning to the numeric example in Table 1 (and assuming for now that counterparties do not adjust their offers in anticipation of cognitive effects), it is easy to rank the three core implementations in terms of predicted incentive effects if we ignore the sunk ex ante compensation or payments and focus solely on the ex post contingent cash flows. From this ex post perspective, the ex ante implementation will produce the greatest incentive effect because it uses the largest stick of $\$ 10,000$. The ex post compensation produces the second largest incentive because it combines a $\$ 6,000$ carrot with a $\$ 4,000$ stick. The wager implementation produces the smallest loss aversion and thus the smallest incentive because it relies solely on a $\$ 10,000$ carrot to induce compliance.

However, our earlier emphasis that the wager implementation is identical to the ex ante compensation implementation coupled with a $\$ 10,000$ deposit is a clue that the ex ante lump sum payments may play a crucial role in whether the ex post cash flows are treated as gains or losses. Suppose that the committing party

\footnotetext{
${ }^{12}$ Indeed any constant $K$ implementation for $\$ 5,000<K<\$ 11,000$ would be feasible given the $\$ 5,000$ liquidity constraint.

${ }^{13}$ See generally Amos Tversky \& Daniel Kahneman, Loss Aversion in Riskless Choice: A Reference-Dependent Model, 106 Q.J. ECON. 1039 (1991) (exploring the evidence for and consequences of losses having greater impact than gains).
} 
treats gains and losses equivalently, but suffers from a sunk cost fallacy. ${ }^{14} \mathrm{~A}$ committing party who starts off paying $\$ 4,000$ under the wager implementation may work harder to avoid losing this money for good. Meanwhile, just as gamblers who get ahead in their initial bets show a great willingness to play with "house money," committing parties who start off with a $\$ 6,000$ payment may treat the prospect of forfeiting $\$ 10,000$ as really just a $\$ 4,000$ net loss. Thus, if we imagine that parties count sunk costs (and do not deduct them from possible gains) and ignore already received benefits (deducting them from possible losses), then the wager implementation produces the largest incentive effect, and the ex ante version produces the smallest.

The loss aversion dominance of the wager implementation over the ex ante implementation on these assumptions should impact the amount that counterparties are willing to offer to the extent that counterparties believe that committing parties "suffer" from loss aversion. For example, if the presence of the initial $\$ 6,000$ payment makes the ex ante implementation feel like only a $\$ 4,000$ incentive, counterparties might expect a lower probability of success. They would then be willing to offer even more than $\$ 6,000$ for the chance to earn $\$ 10,000$. Under this reasoning, a $\$ 7,000$ or $\$ 8,000$ initial payment would further undermine the perceived incentive effect. But rather than complete unraveling, in equilibrium we would ordinarily expect inflated payments that still allowed for some probability of success. While it is tempting to think of these higher ex ante bids as a good thing, they are driven by a market assessment that the commitment device would have a lower probability of being effective.

Another relevant behavioral possibility is that hyperbolic discounting might lead committing parties to have time-inconsistent preferences. ${ }^{15}$ (For simplicity, we have so far ignored standard discounting, though it would be straightforward to adjust the payments for the time value of money.) Hyperbolic discounting causes people to exhibit "present bias" because they sharply discount any cash flows that are received in the future, regardless of how far in the future they are received. For example, behavioral economists Ted O'Donoghue and Matt Rabin make an extreme, but simplifying, assumption that hyperbolic discounters cut the value of any future reward in half - whether it is 1 or 100 weeks in the future. ${ }^{16}$ Under this assumption, a committing party who is a hyperbolic

\footnotetext{
${ }^{14}$ See generally Thomas Kelly, Sunk Costs, Rationality, and Acting for the Sake of the Past, 38 Nô̂S 60 (2004) (exploring the sunk cost fallacy and arguing that honoring sunk costs is sometimes rational).

15 See, e.g., Fernando S. Machado \& Rajiv K. Sinha, Smoking Cessation: A Model of Planned vs. Actual Behavior for Time-Inconsistent Consumers, 26 MKTG. SCI. 834 (2007) (exploring the implications of hyperbolic discounting and time inconsistency among smokers).

16 Ted O’Donoghue \& Matthew Rabin, Optimal Sin Taxes, 90 J. PuB. ECON. 1825 (2006).
} 
discounter would experience the three core implementations described in Table 1 as if they produced the following cash flows:

Table 3. Possible effects of hyperbolic discounting

\begin{tabular}{|l|l|l|l|} 
Implementation & $\begin{array}{l}\text { Ex ante } \\
\text { compensation }\end{array}$ & $\begin{array}{l}\text { Ex post } \\
\text { compensation }\end{array}$ & Ex post forfeiture \\
\hline Ex Ante & $\$ 6,000$ & 0 & $-\$ 5,000$ \\
\hline Ex Post & 0 & $\$ 3,000$ & $-\$ 2,000$ \\
\hline Wager & $-\$ 4,000$ & $\$ 5,000$ & 0 \\
\hline General & $\$ 6,000-K$ & $K / 2$ & $K / 2-\$ 5,000$ \\
\hline
\end{tabular}

This table shows that hyperbolic discounting is likely to push toward favoring the ex ante implementation. A hyperbolic discounter "feels" the full benefit of a $\$ 6,000$ compensation for what, from the ex ante perspective, feels like putting $\$ 5,000$ at risk. In contrast, the ex post implementation equally discounts the carrot and the stick, producing less attractive implicit odds, while the experience of odds of the wager are worst because the hyperbolic discounter is forced to deposit $\$ 4,000$ ex ante for the chance to receive what "feels" like a chance at $\$ 5,000$.

Indeed, the ex ante implementation flips one of the core results of the hyperbolic discounting literature. Writers have suggested that the most severe barrier to entering into commitments is that hyperbolic discounters must be sophisticated enough to know that they have a problem. ${ }^{17}$ For example, a naïve hyperbolic discounter who puts off an unpleasant task (a cost) today, but nonetheless believes that she will not put it off in the future, may not feel like she needs help strengthening resolve. She believes (incorrectly) that she will stop procrastinating all by herself. Under this theory, naïve hyperbolic discounters are unlikely to demand commitments to increase their resolve: They procrastinate now, but they do not think they will have a problem with procrastination in the future.

But ex ante implementations flip the impact of naïveté. Because the naïf does not think that she will have a weakness of will in the second period, she will overestimate the objective probability of success. For a naïve hyperbolic discounter, the market's proffered ex ante payment will seem overly generous, both because it is an immediate payment and because it is in return for what a naïve hyperbolic discounter will think is a very low probability of forfeiture. However, the prospect of this future forfeiture will nonetheless have an impact in

\footnotetext{
${ }^{17}$ See, e.g., Jonathan Gruber \& Botond Köszegi, Is Addiction "Rational"? Theory and Evidence, 116 Q.J. ECON. 1261, 1279 (2001) (labeling a subset of hyperbolic discounters as "naïve" because "they do not understand that they cannot make consistent plans through time").
} 
raising success rates as the time horizon shrinks and the committing party comes closer to the time of potential forfeiture, when the potential loss is no longer discounted. What initially felt like just a potential $\$ 5,000$ loss will blossom into a potential $\$ 10,000$ forfeiture as time elapses and the future becomes the present.

The naïve hyperbolic discounter will consider the proffered compensation from an ex ante implementation to be better than a fair bet. In essence, as long as the counterparties offering compensation are more sophisticated than the committing party in their knowledge of the committing party's likely continuing willpower problem, the proceeds of the commitment bond will seem beneficent. The counterparties' heightened sophistication can substitute for the committing party's lack of sophistication. O'Donoghue and Rabin argue that most humans "exhibit a tendency to pursue immediate gratification in a way that they themselves disapprove of in the long run." 18 But ex ante implementations harness this urge to pursue immediate gratification to encourage participation in taking on longer term commitment risks.

\section{B. Commitment Auctions}

One way to effectuate compensating commitment bonds would be to use an auction. Specifically, counterparties would serve as bidders, and the highest bidder would win the right to receive any future forfeit of the committing party. As we will discuss, such an auction mechanism (in all three implementations) both has informational benefits and creates the opportunity for the bonding process to aid in the process of goal setting itself.

\section{Informational Benefits}

Aside from providing a means for committing parties to solicit offers of compensation from counterparties, auctions provide an independent benefit in potentially providing the committing parties with information that can make them more sophisticated. All of the implementations - including the auctions that would pay ex post compensation - have ex ante determinations of contractual terms from which the implicit probability of success can be determined. For example, imagine an ex post compensation auction where the high bidder offers to pay $\$ 70$ contingent on commitment success in exchange for a chance to earn $\$ 100$ if the commitment fails. From this winning bid, we can infer that the market measures the probability of success to be $58.8 \% .^{19}$

\footnotetext{
${ }^{18}$ O’Donoghue \& Rabin, supra note 16 , at 1828.

$1958.8 \%=1-(70 / 170)$. More generally, the implicit probability from any of the incentiveequivalent implementations will be $1-((E A C+P V(E P C)) /(P V(E P C-E P F)))$, where $E A C, E P C$ and $E P F$ are defined as before, see supra note Error! Bookmark not defined., and $P V()$ is the
} 
The ability to back out implicit success probabilities ranging from $0 \%$ to $100 \%$ also underscores a key design choice in setting the size of forfeiture amounts. In the terms of Calabresi and Melamed, ${ }^{20}$ commitment bonds can be structured as either liability or property rules. Property rule commitments would have more severe forfeitures that would produce implicit success probabilities closer to $100 \%$. The purpose of property rule commitments would be to deter future failure by taking choice off the table. Liability rule commitments, in contrast, would seek to guide future choice by forcing the committing party's future self to internalize external impacts of failing to keep a commitment. With liability rule commitments, the implicit success could be substantially lower, albeit still higher than it would be in the absence of the forfeiture incentive.

While theory suggests that the implicit probability of success should generally increase as the amount at risk to be forfeited increases, the amount of expected compensation can either increase or decrease as the amount at risk to be forfeited increases. This relationship depends on the elasticity of the probability of forfeiture with regard to size of the stakes. If the probability of forfeiture is inelastic with respect to changes in stakes, then increases in the forfeiture amount will tend to increase the offered ex ante compensation. ${ }^{21}$ Counterparty bidders will

present value at time of auction of future cash flows.

${ }^{20}$ Guido Calabresi \& A. Douglas Melamed, Property Rules, Liability Rules, and Inalienability; One View of the Cathedral, 85 HARV. L. REV. 1089 (1972); see also IAN AYRES, OPTIONAL LAW: THE STRUCTURE OF LEGAL ENTITLEMENTS (2005);

${ }^{21}$ In an ex ante compensation auction, the ex ante compensation from a commitment as a function of the ex post forfeiture is: $E A C(E P F)=P(E P F) * E P F$,

Where $E A C()=$ ex ante compensation,

$E P F=$ ex post forfeiture at risk, and

$P(E P F)=$ probability of forfeiture of stakes give $E P F$.

Using the trusty tools of introductory economics, we can minimize the expected Forfeiture by finding the stakes that make:

$$
\mathrm{d} E A C / \mathrm{d} E P F=P(E P F)+(\mathrm{d} P / \mathrm{d} E P F) * E P F=0
$$

which can be restated as:

$$
P / E P F=-\mathrm{d} P / \mathrm{d} E P F \text {. }
$$

If we assume that people will work harder to keep their commitment when the stakes are increased, then $\mathrm{d} P / \mathrm{d} S$ is likely to be less than zero. Equation (2) implies that the ex ante compensation on a commitment contract will be minimized when: $-(\mathrm{d} P / \mathrm{d} E P F) /(P / E P F)=e=1$

where $e$ is the elasticity of the probability of forfeiture with respect to the stakes. As long as the probability of forfeiture is elastic, the ex ante compensation will decrease with increases in the size of the forfeiture amount. Or to put it slightly more simply, so long as the percentage reduction in $P$ is greater than the percentage increase in $E P F$, ex ante compensation will increase with reduction in stakes. For sufficiently high stakes if the probability of forfeiture remains greater than 0 , there are good reasons to assume that the responsiveness of the probability will become inelastic, so that the ex ante compensation will begin to increase with the forfeiture amount. 
pay more for a greater potential forfeit reward. But if the probability of forfeiture is sufficiently elastic with respect to an increase in the stakes, then increasing the forfeiture amount will decrease the ex ante compensation. The reduced probability of a forfeiture in this case more than compensates for its increased size. $^{22}$

A committing party who naively overestimates the probability of success would need to confront bidders' skepticism (evidenced by bidders' willingness to offer large ex ante compensation). Market feedback indicating that willpower problems may extend into the future might itself improve the committing party's sophistication. This ex ante information might help committing parties change their behavior. A committing party who learns that the implicit probability of success is too low might react by raising the stakes to increase the probability of success.

\section{Goal Setting Auctions}

Instead of backing out an implicit probability of success for a prespecified goal, it is possible to structure commitment auctions over goal-setting itself in order to achieve pre-specified probabilities of success. For example, with regard to weight loss, it is well established in the literature that dieters have a tendency to set unrealistically large weight loss goals. ${ }^{23}$ In our earlier implementations, the auction contract specified the goal (for example, the number of pounds the party intends to lose by some date) and two of three cashflows (ex ante compensation, ex post compensation, or ex post forfeiture). The auction would then be conducted on the unspecified cashflow to find the bidder that was willing to offer the most advantageous term on this dimension.

In contrast, under a goal-setting auction, the committing party would set all three cashflows and would then allow bidders to compete on who would offer the most easily achieved goal. Pre-specifying the three cashflows would mean implicitly specifying the required probability of success. The auction bids would then determine the goal that would produce that requisite probability. For example, imagine that a 250-pound Rush specified $\$ 1,000,000$ as an ex post forfeiture, $\$ 0$ as ex post compensation, and $\$ 400,000$ as ex ante compensation in a

\footnotetext{
${ }^{22}$ In ongoing commitments with the possibility of multiple forfeitures or forfeitures of different amounts, it will not be possible to back out a single probability of success.

${ }^{23}$ Most obese people want to lose a lot more than a realistic 10\% of their body weight. A 1997 study of obese dieters found that most wanted to lose more than $30 \%$ of their initial weight. Gary D. Foster et al., What Is a Reasonable Weight Loss? Patients' Expectations and Evaluations of Obesity Treatment Outcomes, 65 J. Consulting \& Clinical PsyCHOL. 79 (1997). The National Institute of Health recommends an initial goal of no more than $10 \%$. NIH, Guidelines on Overweight and Obesity: Electronic Textbook, http://www.nhlbi.nih.gov/guidelines/obesity/e_txtbk/txgd/4311.htm.
} 
commitment contract for him to lose $X$ pounds by the end of the year. The prespecified cash flows would be a fair bet if Rush had a $60 \%$ of losing $X$ pounds. $\mathrm{He}$ could hold a Dutch auction where bidders competed by offering successively lower $X$ 's. ${ }^{24}$ The bidder offering the lowest $X$, the most easily achieved weightloss goal, would win the auction and be obligated to pay the $\$ 400,000$ in ex ante compensation.

As in other contexts, it would be possible for the committing party to include a "reserve price" for the auction. For example, if it would not be healthy to lose more than $100 \mathrm{lbs}$, the initial auction could specify that the initial bids had to be less than that amount. Not all contexts are equally amenable to goal-setting auctions. Some commitments by their nature are all-or-nothing affairs. For example, commitments to quit smoking or to do your taxes on time are not as divisible as a weight-loss commitment. Even smoking cessation commitments, however, might be differentiated by number of cigarettes a day or the speed to cessation.

It is also possible to use auctions to help choose the most effective forfeiture amount. Instead of specifying the three cash-flows and having the bidders compete in offering the most advantageous goal to the committing party, it is possible for the committing party to specify the goal and the desired ratio of compensation to forfeiture and then have bidders compete on the minimum forfeiture that will produce the desired probability of success. For example, imagine that Barack wants to enter into a commitment contract to quit smoking by the end of the year and wants to have at least a $75 \%$ chance of success. He could auction a commitment to quit smoking where he promises as a contingent forfeiture to pay four times the amount of any ex ante compensation. The bidders would then compete by entering successively higher offers of ex ante compensation. For example, if Barack would have a $75 \%$ chance of success with $\$ 1,000,000$ at risk, then a competitive auction would produce bids of ex ante compensation close to $\$ 250,000 .^{25}$

Stepping back, we have shown not only that compensating commitment bonds radically reduce the price of making credible commitments, but also that commitment auctions can be implemented in a bewildering array of incentive-

\footnotetext{
${ }^{24}$ The auction equally could be conducted as a silent auction, with the bidder offering the lowest $X$ announced as the winner when the bids are revealed. The contract would then be for that value of $X$, or alternative for the second-lowest value of $X$. This would make the auction akin to a Vickrey second-price auction, which induces bidders to make the most favorable bids that they would be willing to accept. See William Vickrey, Counterspeculation, Auctions, and Competitive Sealed Tenders, 16 J. FIN. 8 (1971).

${ }^{25}$ An analogous commitment auction was proposed to privatize the setting of bail bonds to assure that defendants had a sufficient probability of showing up for their trial. See Ian Ayres \& Joel Waldfogel, A Market Test for Race Discrimination in Bail Setting, 46 StAN. L. Rev. 987 (1994).
} 
equivalent ways that would allow committing parties to respond to a variety of cognitive, liquidity and information barriers. The case for compensating commitment contracts is strengthened by considering things like time-inconsistent preferences and naïve, self-serving bias. Moreover, the market dimension of these auctions can be harnessed to help committing parties choose more realistic goals or more effective stakes.

\section{COMMITMENT BY THE GOVERNMENT}

Our discussion so far has focused on use of commitment bonds by singleentity private parties. We now consider the government as an example of such an entity. We begin by considering whether the government may sell compensating commitment bonds. In the United States, existing law is ambiguous, but there are strong arguments for enforcing commitment bonds in at least some instances. We then consider various possible uses of commitment bonds. Although we sometimes use the U.S. case as an example, these uses could easily be adopted in other countries as well if compensating commitment bonds are permissible under their laws. We identify three classes of potential uses of commitment bonds: to ensure continued commitment to broad principles, to signal third parties to affect their behavior, and to facilitate political compromise.

\section{A. The Legal Status of Governmental Commitment Bonds}

Most of the analysis in this Article is applicable to any country or government, but here we focus specifically on the United States. We find no clear answer in the existing legal literature or case law as to whether the federal government may use compensating commitment bonds; indeed, if there were such an answer, the originality of this Article might well be called into question. Nonetheless, we argue that there may well be normatively attractive reasons for the government to enter into commitments, and that at least when these reasons are applicable, this should factor into any judicial analysis of commitment bonds.

Assuming that legislatures are generally not allowed to entrench their decisions and that indirect attempts to entrench may be constitutionally problematic, we believe that courts might enforce governmental issuance of commitment bonds, subject to the restriction that the bonds are consistent with legitimate means and legitimate ends. First, with regard to legitimate means, the commitment must be sufficiently weak so that there remains a reasonable probability that the government will fail to meet its commitment. The commitment bond might legitimately force future government decisionmakers to internalize the true cost of their decisions in making a future decision, but it should not take the decision off the table. In the terms of Calabresi and 
Melamed, ${ }^{26}$ government bonds should implement liability rules and not property rules. Second, with respect to legitimate ends, government commitment needs to be motivated primarily as an effort to attain a legitimate goal. This would preclude the government from using commitment bonds to encourage ends that it could not insist on directly (for example, because those ends are unconstitutional). It would also prevent the government from issuing commitment bonds solely to preserve political victories, absent some sufficiently persuasive neutral reason for entrenchment.

Proceeding on the assumption that the government at least sometimes can enter into commitment bonds, we explore some potentially legitimate reasons for the government to enter into commitment bonds. Some of these reasons for allowing government commitments-allowing legislators to commit to higherorder principles that it otherwise would not have the fortitude to keep and signaling third parties about the government's intentions-are direct parallels of the motivations for commitment bonds more generally. Another reason, facilitation of political compromise, is more specific to the legislative process.

\section{The Ambiguity of Existing Law}

A complete analysis of the permissibility of commitment bonds under U.S. law is beyond our scope, though we hope to identify the basic arguments on both sides and to suggest that normative factors might well influence legislative decisions about whether to enter into commitment bonds and judicial decisions about whether to enforce them. Commitment bonds may be legal if either (a) the Congress in general may pass a law that prevents a subsequent Congress from overturning it by a simple majority vote; (b) Congress cannot do so, but can take any other action within its enumerated powers that may as a practical matter have the effect of indirectly constraining future Congresses; or (c) Congress can only take some actions that may constrain future Congresses, but commitment bonds are among the actions that it is permissible for Congress to take.

In 2002, Eric Posner and Adrian Vermeule argued that one Congress could entrench a later Congress. ${ }^{27}$ They suggested a number of reasons that entrenchment might be normatively beneficial, ${ }^{28}$ including that entrenchment may allow the government to obtain better terms in dealings with third parties ${ }^{29}$ and that commitment enhances legislative predictability. ${ }^{30}$ They argue that the

\footnotetext{
${ }^{26}$ See supra note 20 and accompanying text.

${ }^{27}$ See Eric A. Posner \& Adrian Vermeule, Legislative Entrenchment: A Reappraisal, 111 YALE L.J. 1665 (2002).

${ }^{28} I d$. at $1670-73$.

${ }^{29} \mathrm{Id}$. at 1671.

${ }^{30} \mathrm{Id}$. at 1672.
} 
constitutional text does not prevent entrenchment, ${ }^{31}$ and that history supports its use. $^{32}$ John McGinnis and Michael Rappaport counter these arguments, maintaining that although the Constitution may entrench itself against amendment, legislation cannot do so. ${ }^{33}$ Perhaps their most powerful argument is that it was commonly believed at the Founding that legislators could not entrench themselves, ${ }^{34}$ and that the Antifederalists could have been expected to object if the Constitution were understood as deviating from this understanding. Stewart Sterk also counters Posner and Vermeule's normative arguments, emphasizing that if legislators have imperfect foresight, the entrenchment tool may do more harm than good. ${ }^{35}$

All of these commentators, however, acknowledge that one Congress can constrain a later Congress to a great extent through its decisions, particularly through decisions to enter into contracts. For example, Posner and Vermeule emphasize that "[a] government contract, like an entrenching statute, imposes a cost-albeit fiscal rather than political —on future legislatures that seek to escape the consequences of the earlier action." ${ }^{36}$ Sterk also notes that it is permissible for government to enter into contracts, though he notes that this may be justified in part by the fact that "[b]uilt into contract law is a significant safety valve: the parties to the contract can always renegotiate." 37 McGinnis and Rappaport, meanwhile, view government contracts as an exception to the general antientrenchment rule, ${ }^{38}$ and they note that " $[\mathrm{t}]$ he strongest case for . . . entrenchment of public contracts is for debt contracts," 39 because they lower the cost of government borrowing. They note, however, that "debt contracts present a serious problem" because "government agents will sometimes use this borrowing authority to shift onto future generations the costs of spending that benefits only the present generation." 40

McGinnis and Rappaport further note that this exception may be justified only because "the traditional constitutional rule that emerged during the nineteenth century ... strongly presumed that governments cannot contract away

\footnotetext{
${ }^{31}$ Id. at $1674-78$.

${ }^{32}$ Id. at $1678-80$.

33 See John O. McGinnis \& Michael B. Rappaport, Symmetric Entrenchment: A Constitutional Normative Theory, 89 VA. L. REV. 385 (2003).

${ }^{34}$ Id. at 390-96.

35 Stewart E. Sterk, Retrenchment on Entrenchment, 71 GEO. WASH. L. REV. 231, 240-44 (2003).

${ }^{36}$ Posner \& Vermeule, supra note 27 , at 1701.

${ }^{37}$ Id. at 242-43.

${ }^{38}$ McGinnis \& Rappaport, supra note 33, at 434-36.

${ }^{39}$ Id. at 435.

${ }^{40}$ Id.
} 
their sovereign powers." ${ }^{41}$ More recent Supreme Court case law, however, treats the sovereign acts doctrine narrowly. For example, in United States v. Winstar Corp. ${ }^{42}$ the Court rejected a claim that the United States could escape contractual obligations to financial institutions on account of a legal change. The Court acknowledged that a "public and general" act of the sovereign could support the government in seeking discharge of a contractual obligation. ${ }^{43}$ In general, "that defense is traditionally unavailable where the barrier to performance arises from the act of the party seeking discharge," 44 but this general rule does not apply when the government acting as sovereign can be distinguished from the government acting as contractor. ${ }^{45}$

In Winstar, the government could not escape liability because the statute was attributed to the government acting as contractor. ${ }^{46}$ More importantly, for present purposes, the Court announced a clear "holding," "that a governmental act will not be public and general if it has the substantial effect of releasing the Government from its contractual obligations." ${ }^{" 47}$ Importantly, the Court never even considers the argument that the contract should be invalidated because it might constrain a later Congress (such as the one that in fact enacted legislation that led to large contractual obligations). If the Court were concerned about contracts unduly entrenching government policy, then it would be logical to say that the more central the contractual obligations are to a government policy, the stronger the case that the contract must yield to policy. The Court adopts precisely the reverse distinction, limiting liability to situations in which the sovereign adopts a general law that indirectly affects contracting parties.

Admittedly, this does not allow a decisive prediction of how the Court might treat a compensating commitment bond. Perhaps a case involving a commitment bond would lead the Court to shift the analysis from a determination of what capacity the government has acted in to an inquiry into whether contracts unduly interfere with government policymaking. The strongest argument for barring commitment bonds-or more plausibly, for finding unconstitutional some subset of commitment bonds-is that they do not serve the typical functions of contracts and are expressly intended to contract away a nation's sovereign

\footnotetext{
${ }^{41}$ McGinnis \& Rappaport, supra note 33, at 436.

${ }^{42} 518$ U.S. 839 (1996).

${ }^{43}$ Id. at 895 (citing Horowitz v. United States, 267 U.S. 458 (1925)).

${ }^{44} I d$. at 895 .

${ }^{45} \mathrm{Id}$. at 895-96.

${ }^{46}$ An interesting hypothetical is whether the government could have escaped liability if it explicitly extinguished its contractual obligations in the new statute. See infra note 60 (discussing analogous issues for commitment bonds).

${ }^{47} 518$ U.S. at 899.
} 
powers, or at least to constrain future governmental action. Whether the Court would find this problematic presumably depends in part on the normative case for allowing entrenchment with commitment bonds. We now turn to a brief normative evaluation, including an analysis of potential limits on commitment bonds that would alleviate entrenchment concerns.

\section{A Normative Evaluation}

Government commitment bonds would be most problematic if used to attempt to accomplish indirectly what the legislature could not constitutionally compel directly. For example, imagine that a commitment bond provided for a trillion dollar payment to the bondholders if a woman were ever elected President of the United States. A legislative provision declaring women ineligible for the Presidency would be unconstitutional. ${ }^{48}$ Yet this commitment bond, while not foreclosing the possibility altogether, might make it considerably more difficult for a woman to ascend to the Presidency. An old principle of constitutional interpretation is that the legislature cannot accomplish indirectly what it is prohibited from accomplishing directly. ${ }^{49}$ This principle is not taken as seriously today, ${ }^{50}$ however, and commentators routinely label the Supreme Court's jurisprudence on the related unconstitutional conditions doctrine incoherent. ${ }^{51}$ Nonetheless, we believe that the Supreme Court would find some basis for finding such a commitment bond unconstitutional.

The more difficult case is the determination of whether entrenchment through commitment bonds can be unconstitutional when there is no specific constitutional concern other than with the entrenchment itself. The case for unconstitutionality is likely to be strongest when the only purpose behind a commitment bond is to entrench a current majority over a current minority. For example, we might imagine that a narrow Republican minority might use commitment bonds to entrench the Contract with America, or that a narrow Democratic majority might use commitment bonds to entrench a health care reform plan. There may not be any obvious textual basis for striking down such a

\footnotetext{
${ }^{48}$ McGinnis \& Rappaport, supra note 33, at 403.

${ }^{49}$ See, e.g., Dred Scott v. Sandford, 60 U.S. 393, 527 (1856) ("Congress cannot do indirectly what the Constitution prohibits directly.").

50 See Frederick Schauer, Too Hard: Unconstitutional Conditions and the Chimera of Constitutional Consistency, 72 Denv. U. L. Rev. 989, 994 (1995) (stating that the "rhetoric of 'the government cannot do indirectly what it cannot do directly' was poppycock if taken seriously").

${ }^{51}$ See, e.g., Richard A. Epstein, The Supreme Court, 1987 Term: Unconstitutional Conditions, State Power, and the Limits of Consent, 102 HARv. L. Rev. 5, 103 (1988); Cass R. Sunstein, Why the Unconstitutional Conditions Doctrine Is an Anachronism (with Particular Reference to Religion, Speech, and Abortion), 70 B.U. L. REv. 593 (1990).
} 
statute, ${ }^{52}$ but suspect that the Supreme Court might find some means of striking down uses of commitment bonds that have no purposes other than to entrench temporary majorities, for example by holding that the commitment bonds are inconsistent with the structure of the Constitution. ${ }^{53}$

Even in these cases, however, defenders of entrenchment may offer an apolitical reason for entrenchment: that they wish to assure citizens that they can rely on the continuation of the program. For example, Republicans could defend a provision of the Contract with America repealing the marriage penalty ${ }^{54}$ by arguing that they can better assure citizens that marriage will not reduce their tax penalty if they can make the change irreversible. And Democrats could entrench a public option in a health care reform bill by insisting that individuals might be hesitant to abandon their private insurance plans for a public plan if there were a chance that the public plan might be abolished and they would no longer have guaranteed continuing coverage from their private plan. It seems likely that one could make arguments along these line, some stronger and some weaker, for virtually any entrenching legislation, whether they are the true motives or not. Legislators could also simply argue that they believe that the government will benefit because the commitment bonds will provide revenue that government officials do not believe they will have to repay. And in many cases, legislators could claim other apolitical motives for entrenchment, some of which we will consider below. ${ }^{55}$

The courts thus have several options. The first is to prohibit all governmental issuance of commitment bonds, and the second is to allow all such use, at least absent constitutional concerns other than entrenchment. The third is to limit commitment bonds, allowing them in some cases but not in others. There are several possible approaches that the courts could take in separating permissible from impermissible commitment bonds.

One approach to limit commitment bonds would be for the courts to try to determine whether the claimed motive is the true motive. Identifying legislative

\footnotetext{
52 One possibility is that the courts might hold that some entrenchments violate Article V. See U.S. CONST. art. V (providing the process for amendment of the Constitution). The argument might be either that a commitment bond provides effectively unrepealable legislation without the safeguards of Article V, or that a commitment bond could discourage use of the constitutional amendment process if a proposed amendment might lead to payout of a bond.

${ }^{53}$ Cf. Printz v. United States, 521 U.S. 898, 905 (1997) ("Because there is no constitutional text speaking to this precise question, the answer to the [plaintiffs'] challenge must be sought in historical understanding and practice, in the structure of the Constitution, and in the jurisprudence of this Court.").

54 Republican National Committee, Contract with America (1994).

55 See, e.g., Paul Brest, Palmer v. Thompson: An Approach to the Problem of Unconstitutional Legislative Motive, 1971 SuP. CT. REV. 95; John Hart Ely, Legislative and Administrative Motivation in Constitutional Law, 79 YALE L.J. 1205 (1970).
} 
motive is difficult, however, both because legislators may successfully disguise it, ${ }^{56}$ and because the very concept of legislative motive may be a fiction in a multimember body. ${ }^{57}$ The courts also might try to determine whether the claimed motives are sufficiently persuasive to justify entrenchment. In the United States, this would require interpreting existing doctrine counseling against legislative entrenchment as applicable only where there are insufficiently persuasive apolitical reasons to allow entrenchment. One might doubt whether the courts can accomplish such substantive analysis apolitically. ${ }^{58}$ On the other hand, the courts might through common law be able to identify situations in which there are strong arguments for commitment bonds. The courts could then limit commitment bonds to these cases.

A second approach in limiting commitment bonds is to permit entrenchment that is not too powerful. We noted above that as the face value of commitment bonds approaches infinity, these bonds become increasingly indistinguishable from straight legislative commitments. ${ }^{59}$ Bondholders will pay almost nothing for a commitment bond with a face value of $\$ 100$ trillion because there is virtually no chance that the government would take any action that would lead to so great a transfer of value. This is true even if the courts would enforce such commitment bonds.

The courts could allow commitment bonds where there remains some reasonable probability that the government will not meet its commitment. For example, the courts might tolerate a statute that would condition the sale of commitment bonds on receipt of at least $20 \%$ of their face value. It is difficult to see how the courts could arrive at a nonarbitrary percentage, but this is a linedrawing problem that courts have overcome in other areas of constitutional law. ${ }^{60}$ An approach along these lines should be especially attractive to those who worry that allowing legislative entrenchment might produce flawed legislation that can only be eliminated through constitutional amendment, as Posner and Vermeule

\footnotetext{
56 See id.

${ }^{57}$ See, e.g., Frank H. Easterbrook, Statutes’ Domains, 50 U. CHI. L. REV. 533, 547 (1983) (arguing that Arrow's Impossibility Theorem suggests that the concept of a single discernible legislative intent may be a fiction).

58 An analogous doctrine is hard look review, and evidence suggests that judges' political affiliations affect decisionmaking in this context. See, e.g., Thomas J. Miles \& Cass R. Sunstein, The Real World of Arbitrariness Review, 75 U. CHI. L. REV. 761, 767 (2008) (summarizing empirical evidence in the EPA and the NLRB context).

59 See discussion supra Subsection II.A.2., p. 24.

60 See, e.g., Maryland v. Shatzer, 130 S. Ct. 1213 (2010) (finding a previous holding governing questioning of suspects inapplicable when a 14-day break in custody occurred); State Farm v. Campbell, 538 U.S. 408, 425 (2003) (noting that in reviewing punitive damage awards, "singledigit multipliers are more likely to comport with due process").
} 
note. ${ }^{61}$ Paying the price of breaking a commitment may be considerably more viable than constitutional amendment.

Our goal is not to determine which approach is normatively the most attractive. We believe, however, that our identification below of potentially useful (though certainly controversial) applications of commitment bonds strengthens the case for allowing at least some commitment bonds, even assuming that courts would reject the Posner-Vermeule approach of permitting outright legislative entrenchment.

Whether this is a satisfactory approach depends in part on how frequently the legislature might be expected to entrench simply to cement the achievements of transitory majorities. We suspect that purely political entrenchments via commitment bonds would be rare. Posner and Vermeule argue that just as legislatures enact sunset clauses because they value flexibility over stability, so too ought legislatures be able to entrench legislation because they value stability over flexibility. ${ }^{62}$ Whatever the merits of this argument, the existence of sunset clauses demonstrates that legislatures will not always seek as much legislative entrenchment as possible. In fact, the median voter in a legislature may be willing to enact legislation only if it sunsets. Often the median legislator will be willing to enact legislation without a sunset clause, only if future legislatures retain unfettered power to change the policy baseline. Thus even the majority party in a legislature is constrained in achieving many substantive policy initiatives favored by its leaders. In this way, political pressures should restrain Congress in using commitment bonds.

\section{Effects of Uncertainty about Constitutionality}

Let us suppose that a particular commitment bond is unconstitutional, either because all commitment bonds are unconstitutional or because there is a problem with a particular one. In practice, what would be the implications of unconstitutionality? Assuming that the commitment bond is structured so that the government would receive money initially from bondholders and pay only if it failed to achieve its objective, one can imagine attempts to block the legislation at two different points in time. As one example, the constitutionality might be challenged by a lawsuit seeking an injunction before the government accepts money from the bondholders. Another challenge could be from the government itself when the government must pay the bondholders for failure to live up to its commitment. A full analysis is beyond our scope, but we can anticipate potential problems for both challenges. Who would have standing to challenge the contract initially? And can the government escape its obligations under a contract on the

${ }^{61}$ Posner \& Vermeule, supra note 27, at 1691-92.

${ }^{62} I d$. at 1672 . 
ground that it might have encouraged unconstitutional actions when in fact the government failed to meet the intended goal?

We suspect that the obstacles to an ex post challenge are smaller than the obstacles to an ex ante challenge. And yet for advocates of commitment bonds as well as opponents, there is a strong argument for resolving the constitutionality of commitment bonds $a b$ initio. Supporters must worry that if there is some danger that bondholders will not be repaid, the government cannot expect to receive as much up front from issuing commitment bonds. ${ }^{63}$ The government might try to compensate for this by making a larger commitment than it otherwise would, but it may be difficult to calculate how large a commitment to make to compensate for legal uncertainty. Furthermore, the variance in outcomes would lower the amount that potential bondholders will pay. Opponents, meanwhile, might prefer to have the bonds invalidated before they have any constraining effect. Thus, if possible, a legislature might want to facilitate a relatively early challenge to commitment bonds, for example by granting statutory standing to any commercial entity that would be indirectly adversely affected. ${ }^{64}$

\section{B. Additional Challenges}

The danger that the courts might refuse to enforce commitment bonds is not the only obstacle to bondholders being paid. As discussed below, two other challenges to the enforcement of governmental commitment bonds are the possibilities of legislative reneging and negative bondholder influence.

\footnotetext{
63 An alternative strategy for the government might be to place assets that would be used to pay holders of commitment bond in escrow in another country, and provide that the bonds should be adjudicated in that country's legal system, with no deference to any rulings by the government's own courts. We doubt that the United States would adopt this strategy, but it might be sensible for a country whose judicial system is not independent enough to ensure that any adjudication of commitment bonds would be sufficiently fair. There should be no obstacle, so far as we can identify, to U.S. courts adjudicating some other country's commitment bonds. There have been examples analogous to this in U.S. legal history. See, for example, the International Claims Settlement Act, 22 U.S.C. $§ 1621$ et seq., which creates the Foreign Claims Settlement Commission (allowing U.S. nationals to bring claims against foreign nations); and the Alien Tort Claims Act, 28 U.S.C. $\S 1350$ (2006), which extends jurisdiction to foreign citizens bringing suit for conduct occurring outside the United States.

64 The difficulty will be constitutional standing doctrine. To bring a challenge, a plaintiff would need to show inter alia an "injury in fact." Lujan v. Defenders of Wildlife, 504 U.S. 555, 560 (1992). This might be satisfied by a showing that the government caused an immediate economic injury by passing a statute authorizing the sale of commitment bonds.
} 


\section{The Credibility of Governmental Commitment}

There are a number of possible actions a legislature could take to retrench on its commitment. ${ }^{65}$ For example, a legislature might pass a statute explicitly extinguishing the rights of bondholders. Or a legislature might pass a statute that violates a prior commitment but provides that it should not be interpreted as doing so. If the legislature casually abandons commitments that it makes through commitment bonds, then government use of such bonds will not be credible. Bondholders will bid much less for the bonds than they otherwise would. The legislature could respond by selling bonds purportedly worth even more to make up for the shortfall, but this would likely make bondholders even more skeptical that the legislature would ever pay up. After all, if the legislature seems unlikely to pay up on a relatively small commitment to which it fails to adhere, it will almost certainly not pay many more dollars for the same commitment.

Even if the legislature theoretically retained the power to renege on commitment bonds, it might not do so. After all, reneging would establish a precedent making it more likely that the government would renege in the future. Auctions for new commitment bonds would then yield much less in revenue. Similar logic helps explain why many borrowers pay off loans from creditors even if it is unlikely that the creditors will sue them for the loans: they hope to be able to borrow more in the future. Legislators may hope both to be able to constrain themselves in the future and to raise money from such commitments. Of course, legislators, like individuals, also may feel some ethical compulsion to meet their promises to others even if they prove unable to meet their commitments to themselves. It is thus possible that a legislature might make credible commitments to pay bondholders should they fail to meet their own commitments, even if the legislature legally may renege on its commitments.

However, this conclusion is far from certain. And a legislature that wishes to sell commitment bonds could benefit if it could not renege on its commitments. The most straightforward way to accomplish this is through a constitutional provision that obliges the government to meet its commitments. In the United States, the Supreme Court has interpreted the Takings Clause of the Fifth Amendment ${ }^{66}$ as helping to serve this function. In Lynch $v$. United States, ${ }^{67}$ Congress purported to cancel some rights under war risk insurance policies that it had issued. The Court conceded that under the doctrine of sovereign immunity, ${ }^{68}$

\footnotetext{
65 The Winstar case discussed above is not directly relevant here, because in that case, the government claimed that it was not liable under the contract for its sovereign act, but did not purport to extinguish its contractual obligations. See supra note 42.

${ }^{66}$ U.S. CONST. amend. V.

67292 U.S. 571 (1934).

${ }^{68}$ Id. at $580-81$.
} 
Congress could at any time withdraw its consent for the United States to be sued. ${ }^{69}$ But it interpreted the cancellation of the insurance contracts as terminating substantive contractual rights, not as withdrawing the right of contracting parties to sue the United States for doing so. ${ }^{70}$ Admittedly this leaves open the possibility that a later Congress could achieve a different result by simply purporting to withdraw the right to sue without affecting the substantive contractual right. Congress might be hesitant to take that step, however, as doing so could undermine not only its ability to issue commitment bonds in the future but also to make commitments to ordinary contracting partners. ${ }^{71}$

It is possible that courts eager to enhance the ability of the government to enter into firm commitments would find some constitutional support for the proposition that the government cannot escape its contractual commitments (except where it has reserved the power to do so in the contract itself). For example, courts might read the Fifth Amendment's Due Process Clause as incorporating principles similar to those of the Contracts Clause, ${ }^{72}$ which is generally understood to apply only to the states, ${ }^{73}$ even though courts have previously rejected this conclusion. Alternatively, courts might find support in the Public Debt Clause of the Fourteenth Amendment. ${ }^{74}$ This Clause appears to protect conventional bonds issued by the United States, ${ }^{75}$ and it may also protect other types of government debts. ${ }^{76}$ The question is whether the federal government, by issuing commitment bonds on the credit of the United States,

\footnotetext{
${ }^{69}$ See, e.g., id. at 581 ("Although consent to sue was thus given when the policy issued, Congress retained power to withdraw the consent at any time. For consent to sue the United States is a privilege accorded, not the grant of a property right protected by the Fifth Amendment.").

${ }^{70} \mathrm{Id}$. at 583 ("It seems clear that it intended to take away the right; and that Congress did not intend to preserve the right and merely withdraw consent to sue the United States.").

${ }^{71}$ See Harold J. Krent, Reconceptualizing Sovereign Immunity, 45 VAND. L. REV. 1529, 1561 (1992).

${ }^{72}$ U.S. CONST. amend. V; U.S. CONST. art. I, § 10, cl. 1.

${ }^{73}$ U.S. ConST. art. I, § 10, cl. 1 ("No State shall enter into any . . . Law impairing the Obligation of Contracts ....").

${ }^{74}$ U.S. CONST. amend. XIV $\S 4$ ("The validity of the public debt of the United States, authorized by law, including debts incurred for payment of pensions and bounties for services in suppressing insurrection or rebellion, shall not be questioned.").

${ }^{75}$ Though specifically targeted at Civil War debt, the Clause is written in general terms. See Michael Abramowicz, Beyond Balanced Budgets, Fourteenth-Amendment Style, 33 TULSA L.J. 561, 582 (1997); see also Phanor J. Eder, A Forgotten Section of the Fourteenth Amendment, 19 CORNELL L.Q. 1, 15 (1933) (concluding that "the intention was to lay down a constitutional canon for all time in order to protect and maintain the national honor and to strengthen the national credit").

${ }^{76}$ See Abramowicz, supra note 75, at 587-89 (arguing, through a focus on the "including" portion of the Clause, that it protects some obligations besides bonds).
} 
would fall within this provision, and there is no historical evidence or case law that produces a clear answer. There is, in short, enough support for American courts to protect constitutionally a commitment that would make governmental issuance of commitment bonds credible, but the courts might well choose not to demand enforcement even if they do find commitment bonds constitutional.

\section{Bondholder Political Influence}

Another danger with commitment bonds is a political form of moral hazard. ${ }^{77}$ Bondholders have an economic incentive to try to influence the political process to ensure that the government does not meet its commitments. For example, if the government commits to greater education expenditures, the commitment bondholders might attempt to organize as a political force against increased educational spending. The greater the value of a bond, the more incentive bondholders will have to try to ensure that the government does not meet its commitment. For example, they might give political contributions to candidates who oppose the goal to which the government wishes to commit, or sponsor mass advertising campaigns against the government's goal.

There are three general approaches that the government might take to reduce the danger that bondholders will use their political influence to thwart the government's commitment. The first is to restrict bond sales to entities that seem unlikely to be able to influence the government. If, for example, foreigners are precluded from making political contributions, ${ }^{78}$ then the government might sell the bonds only to foreigners, and further provide that the bonds will be unenforceable if they are later resold to American citizens.

A second approach, and likely a more practical one, would be to ensure diffuse ownership of the commitment bonds. For example, the bonds could stipulate that if at any time, an individual, entity or group or affiliated ${ }^{79}$ individuals or entities comes to own at least two percent of the outstanding bonds, the bonds owned in excess of that percentage will not be redeemable.

\footnotetext{
77 See generally KenNeth S. Abraham, Distributing Risk: InSURANCE, Legal TheOry, AND PuBlic POLICY 14 (1986) (defining moral hazard as the "tendency of an insured to underallocate to loss prevention after purchasing insurance").

78 See 2 U.S.C. $\$ 441$ e (2004) (banning contributions by foreigners); Citizens United v. Federal Election Comm'n, 130 S. Ct. 876, 911 (2010) (reserving the question of whether the ban can be justified by "a compelling interest in preventing foreign individuals or associations from influencing our Nation's political process").

79 To count, an affiliation would need to relate to the bonds. If, for example, twenty percent of bondholders happened to be members of the Roman Catholic Church, that presumably would not be inconsistent with the diffusion requirement. An exception might be if the Church encouraged its members to purchase commitment bonds and later donate them to the government. An association of bondholders, more importantly, could trigger the penalty provisions.
} 
Enforcement of such a requirement might require the ability of the government to investigate possible relationships among bondholders, but it seems plausible that a government could prevent concentrated ownership with such penalty provisions. The goal of diffusing ownership and preventing coordination among bondholders is to ensure that there will be a free rider problem among the bondholders. Each bondholder might like all bondholders donate to political organizations fighting against the government's commitment, but because each has only a small stake in the issue, no bondholder is willing to invest personal resources to advancing this common goal.

A third approach is to prohibit lobbying and related activities by bondholders. It may be impractical to criminalize free speech, but the bonds could provide that anyone who attempts to influence the government not to meet its commitment shall be ineligible to cash any bonds or to transfer them to others. The legislation might be drafted to be neutral, so that any lobbying in favor of the government meeting its commitment would also prevent payment to the lobbying party. The government could establish safe harbors, such as uncoordinated political contributions to individual candidates up to a total of some value, and it will presumably not be practical for the government to identify all de minimis spending anyway. However, this approach should be sufficient to limit the ability of third parties to engage in coordinated campaigns that seek to influence government. The only type of coordination that the bonds should tolerate (indeed, encourage) is coordination of efforts to enforce the bonds.

Some combination of these efforts seems likely to offset enough of any increased incentive to thwart the government's commitment so that the net effect of a commitment bond will still be to make it more likely that the government will meet its commitment than had it not sold commitment bonds. As long as the net effect is in the direction of greater rather than less commitment, the government could always increase the face value of the commitment bonds in order to ensure that it achieves any desired total level of commitment. Of course, if the net effect were to make it less likely that the government would meet its commitment, the government could sell bonds that would pay off if the government made its commitment. This would give private parties incentives to lobby for meeting the commitment, and it could be more effective by insisting on relatively concentrated ownership.

To assess the likely success of a commitment or anti-commitment bond, the government (or any other individual or entity considering issuing commitment bonds) could create a market test. $^{80}$ Before definitively deciding on the

\footnotetext{
${ }^{80}$ The mechanism described here is not the only market mechanism that could be used to make this assessment. An alternative approach would be to use conditional prediction markets. See Michael abramowicz, Predictocracy: Market Mechanisms for Public and Private DECISION MAKING 141-44, 199-204 (2008). An advantage of this approach is that it is difficult to
} 
commitment bonds device, the government could solicit orders for commitment bonds contingent upon different total levels of commitment bond sales. For example, it might conduct auctions for commitment bonds contingent on the government's agreeing to issue a total of $\$ 100,000, \$ 100,000,000$, or $\$ 100,000,000,000 .{ }^{81}$ Or, it could ask bidders to submit their bids as a function of the commitment bond level, so that it can assess demand for intermediate values. The government would promise to refund the money paid at the auctions (with interest) if it did not decide to go through with the sale of commitment bonds at that level. Just as with goal-setting auctions, ${ }^{82}$ the prices at auction would allow the government to obtain at least crude estimates of the market's estimate of the probability that the government would meet its commitment for different possible levels of commitment bond sales. These estimates should be sufficiently accurate to validate or discount the concern that the bonds might have offsetting or negative consequences. The government also might use similar auctions to assess the effects of different bond restrictions on the government's likely success.

\section{Functions of Governmental Commitment}

If commitment bonds are a constitutionally permissible and effective means of improving the government's ability to commit to a course of action, then there are several potential functions that commitment bonds legitimately might serve (besides increasing the future resolve of the committing party). Commitment bonds can credibly signal to third parties the government's commitment in a way that will induce beneficial conduct by third parties. Commitment bonds can also facilitate political compromise where agreement is impeded either by the need to resolve details or by the concern that a particular approach might facilitate later legislative change.

\section{Vindication of Higher-Order Principles}

Just as we may believe that it makes sense to permit an individual to commit his or her forward-looking self that wants to lose weight over a later self that in the absence of a commitment would prefer to eat a piece of chocolate cake, so too might we permit a forward-looking government to commit to some goal that in the absence of the commitment it would gladly sacrifice when confronted with some tempting legislation. One can support constitutions and oppose

manipulate prediction markets. See id. at 28-32.

${ }^{81}$ The government need not take orders for the entire face value of the commitment bonds. For example, to estimate demand for the $\$ 100$ billion in bonds, it might solicit firm orders to buy only $\$ 100$ million in bonds. These firm orders would then become the first sales of the bonds should the government then agree to sell $\$ 100$ billion in bonds.

${ }^{82}$ See supra Part I.B.2. 
governmental commitment bonds, or vice-versa, because the requirements for creating or amending constitutions differ from the requirements for creating commitment bonds. But commitment bonds may be a useful mechanism for accomplishing subconstitutional commitments for limited periods of time, especially when constitutions are difficult to amend or when some imperfect degree of adherence to constitutional principles is deemed desirable.

As we discuss below, keeping a balanced budget and committing to (or against) economic bailouts are two examples of this. Eugene Kontorovich has noted that some constitutional provisions can be interpreted as liability rules rather than as property rules to give the government the ability to override the higher-order principles in the event of exigencies. ${ }^{83}$ Commitment bonds can potentially extend this approach to contexts in which there would be no identifiable party harmed by the government's deviation from its commitment. They also are more flexible than liability rule constitutional provisions, as changing the amount of the commitment bond can allow the government to adjust the degree of its commitment. This way, the government can make either small or large commitments in a particular direction.

\section{a. Budget Balance}

Perhaps the most obvious application of commitment bonds, given past interest in the issue, would be to encourage the government to commit to balanced budgets. While voters may be able to understand the importance of limiting deficits, they may end up supporting politicians who promise more spending and lower taxes, blaming deficits on the spending and taxation choices of political opponents. ${ }^{84}$ This may be because voters have limited information or because they have limited self-control. Let us assume for the sake of argument that we should prioritize voters' beliefs in budget balance over their affection for deficit-financed spending. How best to achieve this?

A constitutional amendment is one possibility, ${ }^{85}$ and many jurisdictions have constitutional provisions insisting on some form of budget balance. But it is also possible to imagine subconstitutional approaches to balanced budget commitment. The Gramm-Rudman-Hollings law ${ }^{86}$ sought to commit the government to balanced budgets by providing for automatic spending reductions

\footnotetext{
${ }^{83}$ Eugene Kontorovich, Liability Rules for Constitutional Rights: The Case of Mass Detentions, 56 STAN. L. REV. 755 (2004).

${ }^{84} 41 \%$ Fine with Budget Deficit if Taxes Are Cut, RASMUSSEN REPORTS, February 3, 2010.

85 See generally Theodore P. Seto, Drafting a Federal Balanced Budget Amendment that Does What It Is Supposed To Do (and No More), 106 YALE L.J. 1449 (1997).

${ }^{86} 2$ U.S.C. $\$ 900$ (1985).
} 
in the event that a budget was not in balance. ${ }^{87}$ Posner and Vermeule point out that this is not a true legislative entrenchment, ${ }^{88}$ because Congress could in any future legislation simply declare an exception to the balanced budget principle. Other legislative approaches seeking to advance balanced budget goals, such as pay-as-you-go requirements, are subject to the same problem. Thus, even if it would be possible to overcome the difficulties with the statute that led the Supreme Court to strike it down, ${ }^{89}$ an alternative approach to improving the government's ability to commit to balanced budgets might be desirable.

A simple commitment bonds approach would provide that if the government runs a deficit in a particular year, it would be required to pay a fixed amount to the holders of the commitment bonds. The commitment bonds could include any exceptions, such as military or economic emergencies, that balanced budget amendments also feature. But this provides no incentives to limit deficit spending once the budget is already in deficit, and a great deal would depend on whether the government is on one side or the other of the balanced budget line. A preferable approach thus would be to make payments depend on the degree to which the government runs a deficit. For example, the government might pay $\$ 0.50$ per dollar of deficit up to $\$ 100$ billion, $\$ 1$ per dollar for the next $\$ 150$ billion, and so on. This would make it more expensive for the government to engage in deficit spending, but it would not necessarily eliminate it altogether.

A significant potential challenge to the use of commitment bonds to reduce the deficit is the possibility of accounting disputes potentially leading to litigation. To the extent that bondholders anticipate litigation, they will pay less for commitment bonds, so the seller of commitment bonds bears the full cost of litigation (or, more precisely, its own actual cost, plus its opponents' anticipated costs). The challenge is to find mechanisms that make dispute resolution relatively inexpensive, yet effective. Of course, balanced budget amendments face similar challenges, and one possible approach is to borrow from the idea of maintaining an "independent scorekeeper." "For example, an administrative agency might be established to determine whether the government has run deficits and to pay off bondholders. Judicial review of such decisions might be limited; agency determinations ordinarily would be subject to the Administrative Procedure Act's "substantial evidence" test. ${ }^{91}$ Assuming that the courts would be

\footnotetext{
${ }^{87}$ See generally Thomas J. Downey, The Futility of Gramm-Rudman-Hollings, 25

${ }^{88}$ Posner \& Vermeule, supra note 27, at 1695-97.

${ }^{89}$ See Bowsher v. Synar, 478 U.S. 714 (1986).

90 See Seto, supra note 85 , at 1514.

915 U.S.C. $§ 556$ (2006) (setting forth the "substantial evidence" test that applies to formal proceedings); Ass'n of Data Processing Serv. Orgs. v. Board of Governors of the Fed. Reserve Sys., 745 F.2d 677 (D.C. Cir 1984) (applying same standard to informal proceedings).
} 
relatively independent, this should make it difficult for the agency to stiff bondholders. Meanwhile, as long as protections are taken to prevent bondholders from influencing political processes, they also seem unlikely to be able to capture the agency. ${ }^{92}$

\section{b. Bailouts}

A balanced budget constraint is a commitment at the center of the workings of government, but government also could use commitment bonds to achieve narrower (yet still potentially important) purposes. Suppose, for example, that Congress worried that the recent economic bailouts had created an unacceptable level of moral hazard. ${ }^{93}$ Congress might then determine that it would be beneficial to commit to not grant bailouts in the future. It might even do so as to specific entities. For example, the government might decide that to prevent excessive risk-taking by Fannie Mae, and to repudiate the widely accepted view that the government implicitly backs its obligations, the government might enter into a commitment bond that would pay off if it assumed any future Fannie Mae obligations. The government might commit to paying a fixed sum in the event it assumed any obligations, plus a variable amount depending on the degree of obligations assumed.

Of course, our purpose is not to advocate for or against this approach. Perhaps such a commitment would be ineffective in preventing excessive risktaking, and the government would then be unable to avoid economic disaster. Perhaps there are better solutions, such as ensuring that no entity is too big to fail $^{94}$ and that the failure of one entity will not produce contagion. ${ }^{95}$ But the example highlights that it sometimes might be useful for the government to enter into commitment bonds for the future at the same time as it does the opposite in the present. Indeed, whenever there is concern that a governmental action would create a bad precedent (in an informal, nonjudicial sense), the government might

${ }^{92}$ Cf. John Shepard Wiley Jr., A Capture Theory of Antitrust Federalism, 99 HARV. L. REV. 713, 742 (1986) (noting that agencies aware of the possibility of capture have sometimes been able to undertake reforms to prevent it).

${ }^{93}$ See, for example, Peter L. Bernstein, What's Free about Free Enterprise?, N.Y. TIMES, Sept. 27, 2008, at BU1; and Sudeep Reddy \& Michael R. Crittenden, Fed's Kohn Concedes Risk in AIG Rescue, Wall St. J., Mar. 6, 2009, for discussions of the moral hazard created by economic bailouts.

${ }^{94}$ See, e.g., Gary H. Stern \& Ron J. Feldman, Too Big To Fail: The Hazards of Bank BAILOUTS (2004) (discussing the problem of credibility and the degree to which governments will not let big banks fail).

${ }^{95}$ See generally Christopher Thorson, Proposals to Reduce Systemic Risk Compared, 28 Rev. BANKING \& FIN. L. 458, 459-60 (2009) (noting that the possibility of contagion can increase systemic risk). 
enter into a commitment bond to refrain from doing the same thing in the future. Of course, if the commitment is justifiable then, it might well have been justifiable earlier, but it may be better for the government to issue commitment bonds than either to create a bad policy precedent or to avoid that precedent by taking an action with large negative consequences in the present or near future.

This highlights an important point about commitment that is sometimes overlooked. Often policy analysis proceeds on the assumption that the government ought to do what it would have committed to at an earlier time had it addressed an issue. For example, patent theorists seek to determine optimal ex ante patent policy and may assume that legal ambiguities should be resolved based on such theoretical considerations, but they do not consider that deviating from these optimal rules in an anti-patent direction may be optimal because the policy developed today will not affect invention in the past. Or, bankruptcy theorists assess the incentives of bankruptcy on the capital markets without acknowledging that many of the distributional effects of changes in the bankruptcy laws will stem from contracts that people have already entered into. Even when governmental commitment to some approach makes sense prospectively, a different approach may make sense retrospectively when the regulations have different incentive effects. The government might simultaneously seek to tie its hands for the future and to untie the binds of the past. Only when the latter task undermines the former task should the government necessarily do now what it wants to commit to doing in the future.

Returning to the bailout context, consider an argument that is the reverse of the one above, namely, that the government should commit to bailing out institutions like Freddie Mac because this helps them maintain a low cost of capital. (As this reversal emphasizes, our theory is agnostic about the appropriate direction of bailout commitments.) This argument is distinct from the argument that the government ought now bail out such institutions because they had an implicit government guarantee. Suppose, for example, that the current costs of the bailout of these institutions would exceed the present benefits. If an implicit guarantee were the only type of government guarantee that were possible, then the government would face a trade-off. Violating its implicit bailout guarantee would weaken the credibility of prospective bailout guarantees. With this hypothetical, the government's optimal strategy is to break its previous guarantee while seeking to strengthen its future guarantees.

Introduction of commitment bonds or some other explicit guarantee mechanism can accomplish this. Even if the public no longer trusts the government's implicit commitments, the commitment bond mechanism will alter the government's incentives should a similar situation arise. If the government does issue commitment bonds-either committing to bailing out or not bailing out an institution-then it will not be as easy to evade the commitment should a 
situation later arise in which there is a tension between present expediency and future commitment benefits. The benefit of commitment bonds is that the government can increase the credibility of a claim that it will take a certain action in the future regardless of the action that it takes in the present. But the cost is that the government does this by genuinely constraining its options in the later period.

\section{Signaling}

The above examples of governmental commitment bonds are analogous to an individual's attempt to use commitment bonds to improve self-control, but there may be signaling aspects as well. For example, an anti-bailout commitment might be useful not only because the government worries that it will not have the self control to ignore a failed enterprise, but also because it hopes to send a signal that will discourage excessive risk-taking. The other commitments discussed presumably also have some signaling function. The anti-deficits commitment may reassure purchasers of federal debt that the government will be able to meet its obligations. There are, however, situations in which the role of signaling may be even larger.

Another example would be an anti-inflation commitment in monetary policy. The literature on commitment mechanisms for monetary policy is welldeveloped, as economists have shown that signals of future policy themselves affect social welfare. More specifically, inflation depends in part on expectations of inflation. ${ }^{96}$ It matters not just how expansive monetary policy will be but also how expansive the public believes monetary policy will be. So central bankers can achieve better results if they persuade the public that they will take actions that will tend to result in low inflation, whatever in fact they actually do afterward. This leads to counterintuitive conclusions, such as that the President's optimal strategy is to choose a central banker who is relatively more concerned about low inflation than the President is. ${ }^{97}$ Of course, this will be most effective if the central bank is relatively independent, and so central bank independence is also justified in part based on its anticipated effect on inflation expectations. ${ }^{98}$

96 See, e.g., Edmund S. Phelps, Phillips Curves, Expectations of Inflation and Optimal Unemployment over Time, 34 ECONOMICA 254 (1967); Lars E.O. Svensson, Open-Economy Inflation Targeting, 50 J. INT'L ECON. 155 (2000).

97 See Kenneth Rogoff, The Optimal Degree of Commitment to an Intermediate Monetary Target, 100 Q.J. ECON. 1169, 1177-89 (1985); see also Alan S. Blinder, Central-Bank Credibility: Why Do We Care? How Do We Build It?, 90 AM. ECON. REV. 1421 (2000).

${ }^{98}$ See Alberto Alesina \& Lawrence H. Summers, Central Bank Independence and Macroeconomic Performance: Some Comparative Evidence, 25 J. MonEY, CREDIT \& BANKING 151 (1993); Blinder, supra note 97; Stanley Fischer, Modern Central Banking, in THE FuTURE OF CENTRAL Banking: The Tercentenary Symposium of The BANK OF England 262 (Forrest Capie et al. eds., 1994); Rogoff, supra note 97. 
Central bank independence and selection of a conservative central banker are thus examples of non-compensating commitment mechanisms.

A compensating approach would be for the bonds to specify an inflation target and promise payment for every basis point by which inflation is exceeded. (Ideally, the inflation rate itself should be measured by an agency independent from both the central bank and executive control.) Especially to the extent that bondholders are outside of the country, this changes the central banker's calculus, leading the central banker to err on the side of low inflation more than he or she otherwise would. It is possible that commitment bonds could be set too high, leading to inefficiently low inflation or even deflation, especially when the effects of policy on inflation are uncertain. But in theory, there is some optimal level of commitment bonds, taking into account factors including the degree to which inflation depends on inflation expectations.

That does not necessarily mean that commitment bonds are the best approach for committing to an anti-inflation policy. There will be some cost to commitment bonds, as the payments received ex ante from bondholders will be somewhat less than the expected ex post payments to bondholders, as a result of the risk that the bondholders are assuming. Choosing a relatively conservative central banker is simpler. But a virtue of anti-inflation commitment bonds is that they do not require the appointment of unaccountable officials who are chosen precisely because they will tend to make decisions that the executive will not like. Additionally, a danger of central bank independence is that it may become difficult to replace officials for reasons other than their degree of commitment to low inflation. Meanwhile, anti-inflation commitment bonds may be superior to mechanical commitments to low inflation policy, such as the constant growth rate rule championed by Milton Friedman. ${ }^{99}$ This is because anti-inflation commitment bonds allow the central banker flexibility to consider all economic circumstances in formulating monetary policy.

Monetary policy is frequently cited in the economic literature as an example of policy that is optimally time inconsistent. Policy is time consistent if one would make the same decisions whether committing to a policy path at the outset (assuming full information availability) or making policy decisions at each point in time. Inflation policy is time inconsistent because one's incentive is to commit to a stricter anti-inflation policy for any particular factual circumstance than one would like to choose if that circumstance actually arises. Another classic example of time-inconsistent policy is government flood relief. ${ }^{100}$ The timeinconsistent policy is to be more cold-hearted than one would be after a flood has

\footnotetext{
99 See Milton Friedman, A Program for Monetary Stability (1960).

100 See, e.g., Louis Kaplow, Incentives and Government Relief for Risk, 4 J. RISK \& UNCERTAINTY 167 (1991).
} 
occurred, because one would like homebuilders to internalize costs of their location decisions. Commitment bonds requiring the government to pay third parties some multiple of whatever they pay flood victims could credibly move the government closer to the time-inconsistent policy by signaling to the public that the government will not be as willing to provide relief.

The flood example illustrates how a government can use commitment bonds to make conditional commitments. With a conditional commitment bond, the bondholders will be paid only if some contingency occurs (flood) and the government fails to meet its commitment to act in a certain way (not compensating). As another example, a country could commit to reducing certain tariffs if another country takes some specified actions to open trade. ${ }^{101}$ The revenues from such bonds would be discounted to reflect both the probability that either condition will not be met (in the trade example, the possibilities that one country would not take the specified action or that the committing country would not follow through on its commitment would both decrease auction revenue). Alternatively, the government might agree to reimburse bondholders if the first condition is not met. An advantage of doing so is that it would be easier to tell from the bond prices what bondholders think the probability of the government meeting its commitment is should the contingency arise.

\section{Facilitating Political Compromise}

Commitment bonds can be used not only to send signals to third parties, but also to improve the operation of the legislature itself by facilitating political compromise. There are at least two means by which commitment bonds can achieve this. First, legislatures unable to agree on all the details of legislation may enact provisional legislative agreements in which they commit to resolving additional issues at a later time. This reduces the chance that strategic bargaining may scuttle attempts at a full resolution. The commitment would be to pass legislation having specific features or meeting identified objectives. By increasing the cost of failing to enact legislation, such a commitment reduces the chance that political adversaries will use some minor issue as reason to withhold support for a compromise. Second, commitment bonds may be used to alleviate the concerns of a group worried that prospective legislation might lead to later legislation that

${ }^{101}$ A legislature could grant the executive branch the power to issue trade-related commitment bonds. This would give the executive substantial power to influence trade policy and reduce the chance of special interests scuttling trade agreements. Commitment bonds may thus be a substitute for procedural mechanisms that seek to prevent special interests from influencing legislation. For example, Congress sometimes grants the President "fast-track" authority to negotiate agreements, which means that it will vote the agreements up or down without amendment. See Trade Act of 1974, 19 U.S.C. $\$ 2191-94$, as amended in 19 U.S.C. $\$ 3803-05$. Congress could achieve a similar effect, reducing its freedom of action, by granting the President commitment bonds authority. 
they would oppose. A commitment bond could be used to make it relatively costly for a later legislature to enact that later legislation. This would compensate for any increase in the probability of that later legislation's occurrence resulting from the initial legislative steps.

\section{a. Provisional Legislative Agreements}

In a provisional legislative agreement commitment bond, the legislature commits to enacting legislation that includes some specified features. It may be useful when a majority of the legislature agrees on certain aspects of a legislative compromise but cannot agree on the details. By committing to agree later on more detailed legislation, the legislature reduces the competing factions' incentives to engage in strategic bargaining, thus enhancing the chance that at least some form of agreement is reached. The statute enacting a provisional legislative agreement itself need not have any binding effect beyond the commitment to pay those who purchase the bonds. This helps explain why it may be more beneficial than a statute that simply sets forth what the competing factions have agreed upon. A statute that simply sets forth vague commitments may be unworkable, meaning that the country will pay a heavy price in litigation and uncertainty if the legislature is unable to reach an agreement. The commitment bonds also ensure that there will be a heavy price for failure to agree, with the bondholders' payment compensating for this.

Suppose, for example, that a legislature is negotiating immigration reform. A majority may have agreed that the country will increase the number of immigrants that it allows in the country to some threshold by some date, and that the country will increase its enforcement of rules against illegal immigration so that the number of illegal immigrants will be no greater than a specified number by that date. But there might be critical disagreements, such as whether there will be an amnesty for current illegal immigrants, as well as countless disagreements on less divisive issues, such as how many immigrants each country will be allotted. The government could commit to increasing the number of immigrants and reducing the number of illegal immigrants by the specified numbers. The commitment bonds allow the legislature to increase the chance of achieving a more complete resolution of an issue.

Even if provisional legislative agreement commitment bonds were to become an accepted and frequently used legislative tool, it will not always be easy to reach provisional legislative agreements. Sometimes, it might be obvious that the provisional agreement will tend to favor one faction over another. For example, there might be widespread agreement on certain aspects of some future health care reform but a gulf on a key issue (say, whether a health reform plan should include a "public option"). If a slight majority of legislators favor a public option, then opponents of a public option might worry that commitment bonds 
ultimately will force them to give up on the issue, and so it will not be possible to persuade them to support the issuance of such bonds. Commitment bonds will be more feasible when there is some plausible middle ground on an issue or compromises that might be made to facilitate agreement. Risk-averse politicians might eschew commitment bonds especially if there would be a potential "winner" and "loser" resulting from their issuance.

\section{b. Sanding of Slippery Slopes}

One reason for difficulty in passing legislation is that one faction may worry that the legislation, though itself beneficial, might have adverse consequences later on. For example, consider the issue of the government possibly creating a gun registry so that it can better track handgun ownership and solve crimes. ${ }^{102}$ Some gun rights activists may not in principle be opposed to the government having this information and may even favor the government using such information to punish the illegal use of guns. But they might worry that this will make it easier for a later legislature to take the further step of confiscating guns via a gun ban.

A commitment bond requiring the government to pay a large sum to third parties should it ever ban guns altogether might help to provide enough support for the registry step. In effect, the commitment bond adds sand to the slippery slope, making it more difficult for later legislatures to slip down. And the steeper the legislation makes a slope, the more sand will be needed to prevent slippage. Importantly, the commitment bond can provide this sand regardless of the underlying reason that the slope is slippery. Eugene Volokh has identified at least six different reasons that a gun registry might facilitate a gun ban. ${ }^{103}$ Even if the reason for the slippery slope is not that gun registration makes confiscation cheaper, the expense of commitment bonds will make a later legislature hesitate to enact them. Volokh offers some mechanisms for countering slippery slopes in general, including making the policy at the bottom of the slippery slope unconstitutional or at least ensuring that the Constitution does not mandate sliding down the slippery slope, ${ }^{104}$ but commitment bonds provide a more general solution.

102 This example is borrowed from Eugene Volokh, The Mechanisms of the Slippery Slope, 116 HARV. L. REV. 1026, 1028 (2003)

${ }^{103} I d$. at 1033-34. The reasons are that "[r]egistration may change people's attitudes," id. at 1033, that registration may be a small change that the public ignores, that registration "may create political momentum in favor of gun control supporters," $i d$., that registration may reduce political support for guns by making it more complex to purchase them, that "[r]egistration may lower the cost of confiscation," and that registration "may trigger the operation of another rule" such as the Fourth Amendment's probable cause requirement to make confiscation easier, $i d$. at 1034.

${ }^{104}$ Id. at 1037. 
A challenge to the use of commitment bonds in the gun registration context is that the bonds might need to be permanent if they are to be sufficiently attractive to gun rights supporters, who may be concerned about the long-term survival of freedom and thus have a long time horizon. ${ }^{105}$ This is not necessarily true, as even commitment bonds that will last only a couple of decades might lead gun rights supporters, or at least median legislators, to conclude that the bonds sufficiently decrease the chance of a gun ban. And by doing so, the bonds might make the overall legislative package attractive. There is no technical barrier to permanent commitment bonds or commitments for the distant future; the bonds can specify that they will pay off whenever some contingency comes to pass. Of course, commitments for the distant future will receive less at auction because of discounting, though legislators presumably also discount the cost of commitments. Indeed, a concern about permanence may be that self-interested legislators will discount distant future commitments more than bondholders, because the legislators will not likely be in office when the bill comes due. It may be too easy to sell out the future for a small present advantage. This is, of course, a problem in other contexts as well, ${ }^{106}$ but commitment bonds aggravate the concern.

A danger is that permanent commitment bonds or commitment bonds for the long-term future may simply be unsustainable, especially if the legislature enters into such a commitment lightly. There is then a danger that the commitment bonds will simply be a mechanism for deferring a problem to the future. This would establish an unrealistic policy baseline that will impose high costs on a future legislature in much the same way that deficit spending may burden future generations. As a prudential matter, it may make sense for the government to sell commitment bonds only when the auction revenues suggest that there is a reasonably high chance that the government will be able to meet its commitment. ${ }^{107}$ The government could ensure this by auctioning separate commitment bonds for different periods and comparing auction revenues to the discounted potential payout. It would then cancel an auction (or perhaps all of the auctions) if the auction revenues were so high that it appeared that there was a sufficiently high chance that the government would not be able to meet its

\footnotetext{
${ }^{105}$ Gun rights supporters often argue that their cause is about conserving freedom. See, e.g., Donald Braman \& Dan M. Kahan, Overcoming the Fear of Guns, the Fear of Gun Control, and the Fear of Cultural Politics: Constructing a Better Gun Debate, 55 EMORY L.J. 569, 577 (2006); Charlton Heston, The Second Amendment: America's First Freedom, in Guns IN AMERICA: A READER 199, 203 (Jan E. Dizard et al. eds., 1999).

106 See, e.g., Richard A. Posner, CATASTRoPhe: Risk AND ReSPONSE 118 (2005) (noting the problem in the context of global warming).

${ }^{107}$ Above, we noted that we also might limit commitment bonds to ensure that there is a nontrivial chance that the government will not meet its commitment. See supra Part II.A.2.
} 
commitment. This approach provides some incentive for potential bondholders to imagine different possible states of the future world and consider carefully what legislators may not, whether or not it makes sense to make that long-term commitment. For example, bondholders would consider whether gun control would be more or less useful in the future. ${ }^{108}$

\section{MutuAL COMMITMENT BondS}

In all of the examples so far, a single entity has attempted to make a commitment by selling commitment bonds. In some of these examples, the purpose underlying the commitment related to a relationship between that party and another party, such as one party using a commitment bond to communicate a signal to another party. Our examples showed that, however, even in the signaling case, it is not essential that the commitment be entered into as a contractual concession to another party. Cooter and Porat disguise the heart of the antiinsurance contract, which is the relationship between a committing party and a third party, by focusing instead on the relationship between a promisor and a promisee. ${ }^{109}$ For example, when a manufacturer sells a commitment bond to a third party with a promise to pay that third party when the manufacturer's products break, it is largely irrelevant whether the manufacturer agrees to do this in its contract with the consumer or binds itself in advance of entering into agreements with consumers.

It might then seem that considering mutual commitments-in which each of two or more parties individually agrees to enter into a commitment-would add no more to the analysis and would merely focus on the subset of cases that Cooter and Porat have already carefully and cleverly analyzed. ${ }^{110}$ True, when parties enter into such mutual commitments, the effects are essentially the sum of the effects of the individual commitments. What is new about mutual commitment bonds is that each party entering into the agreement agrees to constrain itself because it wants another party to constrain itself. One party's commitment is the consideration for another's.

As a simple example, each of two married individuals might be happy with his or her own weight, but each wants the other to lose weight. Thus, the

\footnotetext{
108 An argument that gun control will be less necessary in the distant future is that better surveillance technology may allow authorities to identify illegal use of firearms more easily, thus deterring such use without confiscating guns. See Volokh, supra note 102. But better surveillance technology might also mean that use of guns for self-defense is less necessary. Id. We can, of course, imagine many other analyses, and these arguments depend on the premise that society will choose to adopt widespread surveillance technology.

${ }^{109}$ See supra notes 6-9 and accompanying text.

${ }^{110}$ Cooter \& Porat, supra note 6.
} 
couple might agree contractually that both will enter simultaneously into weight loss commitment contracts. This might be superior to a more standard bet or contractual arrangement between the parties, who might share a bank account and in any event might want each to encourage the other to lose weight rather than to gain it. ${ }^{111}$ There are alternatives to the use of commitment bonds in this example that could provide similar ex post incentives, but, without the compensatory payment provided by commitment bonds, the cost of constraint may be too high. For example, two parties entering into a mutual commitment could simply promise that each will give money to a third party if either of the committing parties fails to live up to its commitment. The possibility of receiving either some up-front compensation from the third party or compensation in the event of success would make this arrangement considerably more attractive.

An appreciation of the possibility of mutual commitment bonds, however, points to some general classes of problems that the bonds can solve and for which simple contractual penalty provisions will be ineffective. One set of cases in which mutual commitment bonds may be useful are those in which multiple entities collectively wish to send a signal to third parties, but the possibility of renegotiation undermines the effectiveness of the signal. Other cases in which the bonds may be useful are those in which parties' conduct is not easily measurable, and those in which the parties have not yet entered into a contract with one another. Section III.A develops these classes in more detail, and Section III.B explores potential legal applications of mutual commitment bonds among private parties as well as among governments to develop these points further.

\section{A. Reasons for Mutual Commitment}

\section{Group Signaling}

The motivation for mutual commitment bonds most akin to that for single entity commitment bonds is the idea that a group of entities may wish collectively to signal or credibly convey information about their future behavior. For example, suppose that a group of electricity generators is concerned about the possibility that the government might devise costly command-and-control regulations to reduce pollution. The coalition wishes to show that it will reduce pollution to socially desired levels without government interference. It might then sell commitment bonds requiring each member of the group to pay some large fine to a third party if that member fails to meet its individual goal. ${ }^{112}$ Once again, the

\footnotetext{
${ }^{111}$ Parties in mutual weight loss commitments may have incentives to jointly defect from their commitments in the future. But the use of third-party referees can at times dampen this opportunism by independently verifying whether or not the individual commitments were kept.

${ }^{112}$ The bonds might further be conditioned on the government's not passing the regulations.
} 
commitment bonds device lowers the cost of credible commitment to a particular goal (in this case, reduced emissions), because of the payments received by each member of the group.

The only difference this rationale has from the signaling rationale explored in Subsection II.C.2. is that a group of separate nongovernmental entities rather than a single governmental entity is entering into the commitment. If an entity is nothing but a nexus of contracts, ${ }^{113}$ this is a meaningless distinction. Nonetheless, there are some particular challenges to using commitment bonds to send a signal in this context. One is that it may be difficult to reach an agreement. When a single entity sells commitment bonds, it need not ordinarily decide which subentity would bear the cost of failure. With multiple legally distinct entities, an agreement must be made about how great a commitment each must make. This can be challenging, as each entity may argue for a lower commitment from itself. At the same time, the commitment bonds mechanism inherently alleviates the problem to some extent, because entities that make deeper commitments will receive larger upfront payments. The mechanism also alleviates the need for continued negotiation among the parties. After the commitments are entered into, each party has an incentive to lower its pollution, and we need not worry about internal conflicts among the entities in determining how self-regulation should proceed.

An alternative to mutual commitment bonds is to have each of a number of a group make commitments to one another. For example, one might imagine a contract among a group of electricity users, with each user promising to pay the others some amount of money if the user fails to meet a conservation goal. In fact, a version of this mutual bond exists in the form of the Chicago Climate Exchange. ${ }^{114}$ An advantage mutual commitment bonds have over this approach is that they greatly reduce the risk of nonenforcement. Each member of a group may be hesitant to sue another member, for fear that it will itself be sued, and so there is a danger that all members of a group will tacitly agree to ignore a goal. This danger will be greater the more homogeneous the group is. Mutual commitment bonds grant the enforcement power to one or more third parties who have no reason to fear retaliation, and so the signal sent by the multiple entities will be more credible, and the incentives to meet the goal will be stronger.

\footnotetext{
${ }^{113}$ See, e.g., Melvin A. Eisenberg, The Conception that the Corporation Is a Nexus of Contracts, and the Dual Nature of the Firm, 24 J. CORP. L. 819 (1999).

${ }^{114}$ Companies that join the Chicago Climate Exchange commit to a $1 \%$ a year reduction in their greenhouse emissions, with the added incentive of gaining credits if they reduce their emissions by more. They can then sell those credits to other participants. And those who do not meet that reduction must buy permits. Companies voluntarily enter into this commitment, with the additional reward of good publicity. See Ian Ayres \& Barry Nalebuff, Your Personal Climate Exchange, FORBES, Oct. 30, 2008, http://www.forbes.com/forbes/2008/1124/148.html.
} 
Mutual commitment bonds also may be useful when it is not possible or practical to assign an individual goal for each member of a group, but possible to establish a collective goal. Suppose, for example, that a number of factories lie alongside a river, and it appears that at least one of these factories is polluting the river above legal limits. The government threatens to impose a much more stringent and expensive monitoring regime. The factories might agree to enter into a mutual commitment bond that would require each factory owner to pay a large fine if pollution exceeds a particular level, regardless of whether that factory owner can be proven responsible. If each factory agrees to pay for the entire liability of pollution, then each factory will have optimal deterrence incentives with respect to its own activities. ${ }^{115}$ Ordinarily, of course, it would be hard to convince the factories to agree to such an arrangement, but the prospect of receiving upfront payments might make the signaling incentive more attractive. Meanwhile, individual factories that are not engaging in excessive pollution might propose such an arrangement as a way of credibly signaling that they individually are not responsible and perhaps exposing those who refuse as the likely wrongdoers. Only firms expecting to bear the cost of changing their polluting activity would have a strong incentive to reject such a proposal.

\section{Unverifiable Conduct}

The factories example also helps illustrate a second situation in which mutual commitment bonds may be helpful: when individual actors engage in conduct that can benefit or harm other actors, but the legal system cannot easily identify such conduct. A similar example can illustrate how such a mutual commitment bond might be useful even in the absence of costs borne by anyone outside the group. Suppose that some fixed number of fishermen own a lake, but overfishing by one or more unknown fishermen is reducing collective welfare. Assume further that there are no simple mechanisms for detecting the identity of people overfishing, but that it is possible to accurately estimate the stock of fish remaining in the lake at the end of the season. The fishermen might agree to enter into mutual commitment bonds in which everyone will be required to pay an escalating amount of money to a third party as the stock of fish falls below some set level. This could be sufficient to deter each fisherman from exceeding its quota, because the profits from overfishing might be less than the payment in the event of failure to reach the collective goal.

Mutual commitment bonds may analogously be used to encourage unverifiable investments that will benefit two or more individuals in a group. The problem of unverifiable investment is a staple of the literature on the economics

115 See Robert Cooter \& Ariel Porat, Total Liability for Excessive Harm, 36 J. LEGAL STUD. 63 (2007). 
of contracts, ${ }^{116}$ which recognizes that contracts are often incomplete and that courts often will not be able to determine whether parties have acted well or badly. Perhaps the paradigmatic relationship in which it is difficult for courts to assess parties' conduct is marriage. In marriage, each party may have suboptimal incentives to engage in activities benefiting the marriage (e.g., taking out the trash, buying small gifts for the partner), because each party receives only half the benefits of a strong marriage. Similarly, parties may have excessive incentives to engage in activities that harm the marriage: of two married individuals, the adulterer alone benefits from cheating, while both spouses will share the negative consequences.

In principle, mutual commitment bonds can help solve this problem. A couple might agree to sell mutual commitment bonds that would require a payment to the bondholder in the event of divorce or separation. Such an approach in principle can increase the incentives of each party to a marriage to make the marriage work, as it would force each spouse to internalize more of the costs of marital failure. Some legal devices may achieve similar effects by imposing costs on divorcing parties-for example, by requiring parties to remain married for some period of time after initially seeking divorce ${ }^{117}$-but they offer couples no upfront benefit for entering into a commitment. This example is an application of Cooter and Porat's insight that anti-insurance can help reduce moral hazard. ${ }^{118}$ Mutual commitment bonds, however, can be used whether or not the broader relationship is cemented by contract: individuals prohibited by law from marrying, for example, might be compensated in advance for entering into mutual commitment bonds that would require them to pay a third party if they cease living together.

Of course, our purpose is not to insist that there is a significant market for mutual commitment bonds by married couples, but rather to illustrate how these bonds may be useful in any relationship in which an individual party may not fully internalize the costs and benefits of his, her, or its actions. For example, mutual commitment bonds could be useful in some contractual settings. Suppose that two contracting parties are to work together on some project. There may be a danger that each will work less than is optimal, especially if a court would not be able to identify who shirked in the event that the project is unsuccessful. A mutual commitment bond, promising to achieve some goal for the project as a whole, can help reduce shirking by giving each party a greater stake in project success.

116 See generally Oliver Hart \& John Moore, Incomplete Contracts and Renegotiation, 56 ECONOMETRICA 755 (1988); Jean Tirole, Incomplete Contracts: Where Do We Stand?, 67 ECONOMETRICA 741 (1999).

${ }^{117}$ See, e.g., Louise Carriere, It's Deja Vu All Over Again: The Covenant Marriage Act in Popular Cultural Perception and Legal Reality, 72 TuL. L. REV. 1702, 1717-45 (1997-1998).

${ }^{118}$ See Cooter \& Porat, supra note 6. 


\section{Strategic Bargaining}

In both the group signaling and unverifiable conduct scenarios, the parties use mutual commitment bonds in a cooperative venture to avoid shirking. But mutual commitment bonds may also be useful when parties' interests are directly adverse. Consider two parties that are disputing ownership of some property. They may have at least one interest in common: the interest in reducing bargaining costs. Entering into a mutual commitment bond can advance that common interest, and the agreement to the mutual bond need not be part of a contract resolving all or even any of their differences. For example, the parties might agree to a contract in which each promises to pay a third party some amount of money (say, $\$ 100,000$ ) if they fail to reach some settlement about the property ownership. Once again, they could agree to such a contract in the absence of upfront payments, but the possibility of failure might then make such a commitment uneconomical.

Such an agreement can reduce a party's incentives to engage in strategic bargaining that might threaten an agreement. For example, sometimes it might make sense for a party in a negotiation to reject a reasonable offer and even terminate negotiations in an effort to try to convince the other party that it genuinely believes that its offer is unreasonable. Bluffing is a familiar tactic in negotiation by a party seeking to capture as much of the surplus of an agreement as possible. The danger is that sometimes, such tactics, especially when engaged in by both parties, may prevent the parties from reaching an agreement at all, or at least delay reaching an agreement. A party deciding whether to bluff must weigh the expected cost of bargaining failure against the expected additional surplus received. A mutual commitment bond increases the cost of bargaining failure, thus making it less likely that a party will engage in strategic bargaining behavior, or at least reducing the extent to which parties engage in such behavior.

A simple numeric example can illustrate the virtues of mutual commitment bonds relative to other commitment devices. Suppose that $A$ and $B$ are negotiating over how to split $\$ 100,000$. If they cannot reach an agreement, neither receives any money. Let us suppose that each estimates that by walking away from the table at a critical point in negotiations, there will be a $10 \%$ chance that the party will be able to receive $\$ 65,000$ instead of $\$ 50,000$, with a $2 \%$ increase in the chance of bargaining failure (i.e., $4 \%$ if both parties walk away). With these numbers, each party will have an incentive to walk away from the bargaining table. (The expected benefit of walking away, $0.10 * \$ 15,000=$ $\$ 1,500$, is greater than the expected cost, $0.02 * \$ 50,000=\$ 1,000$.) The expected loss from strategic bargaining is $0.04 * \$ 100,000=\$ 4,000$. However, if the parties enter into a mutual commitment bond in which each must pay more than 
$\$ 25,000$ in the event that they fail to reach an agreement by the deadline, then neither will have an incentive to engage in strategic bargaining.

As developed so far, it might appear that the parties could fare equally well by simply making a commitment to pay more than $\$ 25,000$ each to a charity in the event that they fail to reach an agreement. Because this commitment would be a sufficient deterrent, they would never have to pay it, and the mutual commitment bond is overkill. But suppose that even with commitment, there is a significant residual chance of bargaining failure, say 10\%. (Thus, if one party walks away, there is a $12 \%$ chance, and if both parties walk away, 14\%.) In this case, the parties' combined total expected payment to the charity would be equal to $\$ 5,000$. This amount is greater than the $\$ 4,000$ expected loss from strategic bargaining, and it would not be rational (philanthropic motivations aside) for the parties to make the commitment to the charity. But if the parties receive a combined $\$ 5,000$, or even somewhat less, from a third party that purchases the mutual commitment bond, then the transaction will be mutually advantageous.

Of course, in real world situations, each party will not have full information about the other party's incentives. Strategic bargaining will often occur when each party is uncertain about how costly bargaining failure will be for the other. Each party seeks to demonstrate that it will not be harmed much by bargaining failure. This may make it hard to enter into negotiations to sell mutual commitment bonds. Nonetheless, it may sometimes be easier to enter into mutual commitment bonds (perhaps with each party putting at risk a different amount) than to resolve the underlying bargaining issue. Mutual commitment bonds are cheap in expected value terms because of the benefit to the parties in the event of success. It may also sometimes be feasible to enter into mutual commitment bonds well in advance of a negotiation, when strategic bargaining may be less likely.

\section{B. Applications}

Our examples of mutual commitment bonds so far have been mostly abstract, designed to illustrate how mutual commitment bonds can address a range of theoretical problems. In this section, we offer some more concrete applications. Our purpose, however, is not so much to advocate them; whether these proposals would be practical depends on a range of considerations beyond the scope of this Article. Rather, the purpose is to demonstrate simply how the possibility of mutual commitment bonds creates new possibilities for institutional arrangements. We will consider first a private context and then a governmental one. 


\section{Commitments among Private Parties}

We have already seen that mutual commitment bonds can be used to reduce the incidence of strategic bargaining in negotiations. Settlement discussions are a type of negotiation, and so mutual commitment bonds could be used to decrease strategic bargaining and increase the likelihood of settlement. For example, the parties could agree that if a case goes to trial, each party would pay a fixed amount of money to the purchaser of a commitment bond. As in any other negotiation, this would reduce the risk that a party would hold out to extract a relatively high proportion of the bargaining surplus. ${ }^{119}$

A principal challenge to reaching such an agreement is adverse selection. ${ }^{120}$ The danger is that parties who expect to have a good chance of settling their lawsuits will sell mutual commitment bonds, depressing the price that purchasers will pay. It may be difficult for third parties to estimate accurately the chance of legal settlement, especially when litigants selling mutual commitment bonds should be united in their desire to persuade third parties that settlement is relatively unlikely. Perhaps a third party can participate in some form of due diligence, scrutinizing the paperwork in both parties' legal offices with their consent and with confidentiality assurances. Mutual commitment bonds may be most feasible when there is relatively little private information about litigation. But when there is relatively little private information, there will be relatively little asymmetric information between the parties, and the probability of settlement will be relatively high anyway.

Mutual commitment bonds thus may be a more useful mechanism for limiting litigation when agreed upon in advance, for example, as part of a system of arbitration. If the sale of mutual commitment bonds is mandatory in some arbitration setting, then the adverse selection problem is greatly mitigated. ${ }^{121}$ Purchasers of mutual commitment bonds will still face uncertainty about how to value them, but they need not worry that the bonds are being sold only because the sellers know that they will have relatively little value. Arbitration systems sometimes use other mechanisms to encourage settlement; for example, final offer arbitration encourages settlement by giving parties incentives to reveal their

\footnotetext{
119 See Geoffrey P. Miller, Preliminary Judgments, 2010 U. ILL. L. REv. 165, 175 (“Another impediment to settlement is the possibility that strategic bargaining may prevent the parties from reaching a compromise even though a bargaining range exists in which it would be advantageous for both to settle.").

${ }^{120}$ Cf. George A. Akerlof, The Market for "Lemons": Quality Uncertainty and the Market Mechanism, 84 Q.J. ECON. 488 (1970) (discussing an analogous problem in the used car market).

${ }^{121}$ See, for example, Michael Abramowicz, On the Alienability of Legal Claims, 114 YALE L.J. 697, 760 (2005); and Benjamin J. Richardson, Mandating Environmental Liability Insurance, 12 DuKE ENVTL. L. \& POL'y F. 293, 312-13 (2002), for discussions on mitigating adverse selection by making purchases mandatory.
} 
honest views of litigation prospects. ${ }^{122}$ Mutual commitment bonds could be a complement to or substitute for other mechanisms that arbitration systems use to reduce legal costs.

A problem with mandating the use of mutual commitment bonds in advance might be that it would be difficult to foresee the optimal size of the mutual commitment bond. The size presumably depends on the stakes in the litigation. For example, suppose that two parties are required to each sell $\$ 1,000,000$ commitment bonds for litigation in which $\$ 1,000$ is at stake. Litigation will almost certainly be averted, but the merits of the case will likely have little bearing on the settlement value. Factors such as which party can more easily sustain a loss of $\$ 1,000,000$ are likely to be as or more important in driving settlement negotiations. Even if the claim is frivolous, it seems likely that many defendants would happily settle for $\$ 500$ rather than risk paying $\$ 1,000,000$. Because mutual commitment bonds can affect settlement dynamics, it is important for them to be set at levels that are neither too small to encourage settlement nor so large as to distort settlement.

One possible solution would be for parties to agree to sell mutual commitment bonds where each party promises to pay to a third party an amount equal to the other party's legal expenses. ${ }^{123}$ This would be useful in cases where a party in litigation may take some action, such as filing a discovery request, which is relatively cheap for it but relatively expensive for the opposing party. Parties may not take such actions if they expected to bear the cost of compliance with their request. With this approach to mutual commitment bonds, each party will expect to bear the full cost of litigation, including its own expenses and its opponents, and thus the full cost of any escalation of the litigation. Even with this approach, parties may spend too much from the parties' joint perspective, because neither party will take into account that any advantage that it seeks to obtain for itself will come at the expense of the other party. But mutual commitment bonds should still help limit legal expenses and encourage settlement.

With this variation, advance agreement to sell mutual commitment bonds is especially important. If one party is expected to bear less litigation expenses than the other, then it would be unlikely to agree to such an arrangement once litigation materializes. But even where legal costs are asymmetric, contracting parties might be able to reach an agreement on mutual commitment bonds as part of broader contract negotiations. From a social perspective, mutual commitment bonds that require each party to bear both parties' litigation costs should be

\footnotetext{
${ }^{122}$ See, e.g., William F. Samuelson, Final-Offer Arbitration Under Incomplete Information, 37 J. MGMT. SCI. 1234 (1991).

${ }^{123}$ See John J. Donohue III, Opting for the British Rule, Or If Posner and Shavell Can't Remember the Coase Theorem, Who Will?, 104 HARV. L. REv. 1093 (1991) (observing that parties can contract around the default rules for paying fees).
} 
especially welcomed, because this will reduce the possibility that asymmetric litigation costs will distort settlement values. That does not mean that it would be socially beneficial for a legislature to require all parties to issue mutual commitment bonds. The bonds may, for example, tend to disadvantage parties that are relatively risk-averse and relatively liquidity constrained.

While parties may sometimes agree both to mutual commitment bonds and to some form of arbitration, advance agreement to mutual commitment bonds alone may have some advantages over agreement to arbitration alone. First, there is a danger that arbitration may tend to favor one party over other parties. A common criticism of arbitration, especially where mandated in form contracts, is that arbitrators may have some incentive to favor the party that has a greater ability to influence the contract in the future. Because mutual commitment bonds do not change the relevant legal decisionmakers, they may lead to less change in substantive outcomes. Second, a principal goal of arbitration is to lower legal costs, but this can be hard to achieve. Lowering the cost of trial (or completed arbitration), for example, increases the chance that parties will be willing to go to trial, offsetting any cost savings. The mutual commitment bonds approach seeks to reduce total legal costs by raising the parties' ex post legal costs from continuing and escalating litigation. With the compensating payments from sale of the mutual commitment bonds, parties paradoxically should end up with lower legal costs. It is plausible that increasing the individual costs of litigation could reduce the total cost even without mutual commitment bonds, but the case is much stronger when the parties receive their expected increase in costs through payments from the bond purchaser.

An agreement to sell mutual commitment bonds may also encourage litigating parties to agree to other forms of arbitration, even when they might not have been able to agree on arbitration initially. Often, it is difficult to generate an agreement to arbitration once a lawsuit materializes, because one party might be expected to benefit more than the other from arbitration. But roughly doubling legal fees will increase the incentives of parties to agree on means of lowering fees. Perhaps the party that would be relatively disadvantaged by arbitration might agree to it in exchange for some concession (for example, an agreement that any damages ultimately granted would be reduced or increased by a modest percentage). Short of arbitration, parties might negotiate agreements to reduce the cost of discovery. ${ }^{124}$ They might even agree by contract to implement some additional form of fee-shifting.

\footnotetext{
${ }^{124}$ Michael L. Moffitt, Customized Litigation: The Case for Making Civil Procedure Negotiable, 75 GeO. WASH. L. REV. 461, 469-72 (2007).
} 


\section{Commitments among Governments}

If governments can use commitment bonds to make commitments in much the same way as any single entity, so too can two or more governments agree to enter into mutual commitment bonds as a way of enforcing their agreements to one another. For example, commitment bonds could serve as a remedial mechanism for violations of bilateral or multilateral accords. For example, governments could use mutual commitment bonds as a mechanism to police trade disputes. Suppose that Countries $A$ and $B$ have entered into a bilateral tariffreduction agreement. The countries could agree that each will auction commitment bonds, with payoffs equal to some multiple of the damages suffered by the other country in the event of a violation of the agreement. ${ }^{125}$ Importantly, the countries would need to agree on the forum in which disputes would be adjudicated; for example, a neutral country or an international organization such as the WTO might decide disputes. There may be some danger that a country would simply ignore the decision of the adjudicator, but the fact that this would undermine the nation's ability to enter into commitments with commitment bonds in the future may make this less likely. Requiring each country to place substantial assets in escrow could also eliminate the concern about noncompliance.

What is most distinctive about this approach is that complaints would be brought by the third party bondholders rather than by the offended state. There are potential advantages and disadvantages to this. An advantage is that there is less risk of trade violations causing international friction. Of course, a wronged state might still complain about violations of treaty obligations, but because it would have no direct role in the enforcement process, it would be easier for each country to offer a muted official response. ${ }^{126}$

The use of commitment bonds would also represent a change in the remedy for trade violations. Under current WTO procedures, a country whose trade rights have been violated is permitted to retaliate against the offending state. ${ }^{127}$ Critics have argued that the remedy aggravates the original offense,

\footnotetext{
${ }^{125}$ For example, say the United States and France were to enter into a trade agreement involving the auction of commitment bonds, with both committing to pay treble damages in the event of violation. Then if the United States were to enact protective tariffs in violation of that agreement and caused $\$ 100$ million in damages, the United States would owe bondholders $\$ 300$ million.

${ }^{126}$ A disadvantage is that there is some risk of overenforcement, though again fee-shifting or other similar devices can reduce this concern. Moreover, overenforcement may be preferable to a regime in which each country is hesitant to act against violations of its trade rights for fear that another country will charge it with violations as well. Commitment bonds reduce the risk that each of two countries will tolerate a reversion to protectionism by the other, in the face of common domestic pressures

${ }^{127}$ Understanding on Rules and Procedures Governing the Settlement of Disputes, Art. 22.2,
} 
leading to reduced trade. ${ }^{128}$ Defending the approach, Jide Nzelibe has argued that the mechanism cleverly takes advantage of the domestic political power of protectionist interests in the wronged state and of exporters in the offending state to ensure that trade rights will be enforced and that violators will yield to the adjudicator. ${ }^{129}$

Mutual commitment bonds should make money damages more attractive, however. Ordinarily, a country may be hesitant to enter into a treaty regime in which it might need to pay money damages. Legislators may focus more on bottom-line budget numbers than on social welfare, and so they may be more willing to tolerate trade retaliation against domestic industry than an equivalent fine. (Of course, this also suggests that monetary damages can have stronger deterrent properties.) The upfront payment that each country should receive from selling mutual commitment bonds may balance the concern about making a later payment in the event of a trade violation. This is especially likely to make a difference if legislators have high or even hyperbolic discount rates, ${ }^{130}$ embracing an immediate infusion into the treasury even when accompanied by a commitment in the future that is likely to be somewhat greater in expected value terms.

As each nation would issue its own bonds, these general considerations can be extended easily to multilateral disputes as well as to disputes in areas other than trade. Conceivably, two nations engaged in physical hostilities might seek to use mutual commitment bonds to enforce a peace accord. Whatever the merits of nations enforcing their treaty rights through trade retaliation, alternatives to military retaliation could be beneficial. A country might be more willing to resist a military response to a perceived violation of an agreement if it knew that third party bondholders would extract a monetary payment. And countries may be more willing to enter into peace accords in the first place if they know that meeting their obligations will provide a financial windfall. Of course, all this depends on warring nations' being able to commit sufficiently well to paying bondholders, which may be impractical for states with limited resources to place in escrow and no history of commitment to the rule of law. ${ }^{131}$

WTO Agreement, Annex 2, 1869 U.N.T.S. 401, 33 I.L.M. 1226 (1994).

${ }^{128}$ Mark Wu, Antidumping in Asia's Emerging Giants (2010) (unpublished manuscript, on file with authors).

129 Jide Nzelibe, The Credibility Imperative: The Political Dynamics of Retaliation in the World Trade Organization's Dispute Resolution Mechanism, 6 THEORETICAL INQ. L. 215 (2005).

${ }^{130}$ See supra notes 15-16 and accompanying text.

${ }^{131}$ For instance, Worldwide Governance Indicators has measured rule of law worldwide. See Governance Matters 2009, WORLDWIDE GOVERNANCE INDICATORS, 1996-2008 http://info.worldbank.org/governance/wgi/worldmap.asp 


\section{CONCLUSION}

This article has sketched a dizzying array of contexts in which committing parties could seek ex ante compensation for taking on a potential risk of making ex post payments if they fail to live up to their commitments. What is more, we have identified a family of incentive-equivalent structures, which vary the timing of contingent and non-contingent cash flows in order to implement these commitments. While the idea of uncompensated commitment devices has been well-understood for decades, the simple but powerful enhancement of fair-bet compensation holds the prospect of substantially reducing the cost of making commitments.

Our goal has not been to provide the nitty-gritty details of implementation, but instead, to provoke a sense of the scope and potential for helping individuals, entities, and even nation states to better achieve their goals. But for those who are skeptical that commitment compensation could never work in practice, we end with this motivating example of what may have been the world's first ex ante implementation of a compensating commitment bond.

On February 22, 2008, James Hurman, a thirty-year-old New Zealander, posted a short video on YouTube offering to "hand over my right to smoke," promising to pay the highest bidder $\mathrm{NZ} \$ 1,000$ "per cigarette that I smoke at any time following the auction's closure." 132 We have described the ex ante auction as selling to the highest bidder the right to be the recipient of any forfeiture payments. But in another sense, James was indeed selling his "right to smoke." Before signing the contract, he had an unfettered right to smoke whenever he wanted. And smoke he did. He estimates that he had smoked 50,000 cigarettes before he entered this contract.

On March 31, 2008, James signed his commitment contract with Kent Pearson. Kent had won the auction for a mere NZ\$300. ${ }^{133}$ James has been under the contract for over a year. His wife had their first baby, Tripp Sander Hurman,

132 A longer description of Hurman's auction story will appear in IAN AYRES, CARROTS AND STICKS ch. 3 at 61 (forthcoming 2010); see also Smoking Habit for Sale, http://smokinghabitforsale.com/index.html (last visited June 15, 2009); Smoking Habit Contract, trademe.co.nz (last visited June http://www.trademe.co.nz/Browse/Listing.aspx?id=146646769. Hurman promised to donate the proceeds from the auction to the Cancer Society of New Zealand.

${ }^{133}$ The auction revenue could be low for two radically different reasons. Bidders could have been convinced that the commitment to pay $\$ 20,000$ a pack assured a very low chance that James would ever fail. See supra text accompanying note 22. Or, bidders could have figured that they would never be able to collect from James even if he did continue to smoke. This auction was the first of its kind - with attendant risks of whether courts in New Zealand would even enforce a severe forfeiture. But the very existence of this example shows that an ex ante auction can produce bids and at least some compensation for taking on the risk of forfeiture. 
on July 21, 2009, and, as of this writing, James has been smoke-free ever since. For those who think that a commitment compensation auction could never work in practice, one answer is that it already has. ${ }^{134}$ And if it can work for a man, why not for other private parties or even for governments?

${ }^{134}$ A version of the wager approach to commitment bonds has also been implemented in England, where the betting agency William Hill takes weight-loss wagers. See Nicholas Burger \& John Lynham, Betting on Weight Loss . . . and Losing: Personal Gambles as Commitment Mechanisms, 16 ApPLIED ECONOMICS LETTERS 1350 (2009); Ayres, supra note 23. For example, Graham Trow won a bet that he couldn't lose 28 pounds in 56 days, where he initially paid in $\$ 68$, and ended up receiving $\$ 1,900$ for his efforts. Even though competing offers from other bookmakers could emulate the outcomes of the auction, the economists Burger and Lynham find the contracted odds made the bets less than fair to people attempting to lose weight. 